\title{
Entrepreneurial Finance Journeys: Embeddedness and the Finance Escalator
}

Ekaterina Murzacheva ${ }^{\mathrm{a} *}$ and Jonathan Levie ${ }^{\mathrm{b}}$

${ }^{a}$ Portsmouth Business School, University of Portsmouth, Portsmouth, UK;

bJ.E. Cairnes School of Business \& Economics, National University of Ireland Galway, Galway, Ireland

* Email: ekaterina.murzacheva@port.ac.uk

Phone: +442392844167

ORCID ID: 0000-0002-6793-4436 


\section{Entrepreneurial Finance Journeys: Embeddedness and the Finance Escalator}

\section{Abstract}

This paper re-visits the traditional model of the finance escalator, which outlines alternative financial pathways for entrepreneurs depending on their aspirations and stage of development. Building on social, spatial and institutional embeddedness perspectives, the dynamic and interactional challenges of financial decisions are captured through an exploratory interpretivist approach. Ten early funding journeys of entrepreneurs in Scotland, all of whom sought external funding, were scrutinized with the objective of revealing motivations, reasoning, and patterns behind funding decisions. Surprisingly, these entrepreneurs all initially sought valueadded financial capital, but issues including control (perceived as ownership), speed of access, and external environmental pressures caused them to accept offers (often unsolicited) from familiar sources. As a result, a revised finance escalator is proposed. The extent to which these findings are context specific is discussed.

\section{Keywords:}

Finance escalator, entrepreneurship, embeddedness, financial decision-making, financial capital

\section{Word count: 9472}




\section{Introduction}

This paper addresses the research question: how do internal motivations of entrepreneurs, and their perception of external drivers inform their funding decisions? Academics seeking answers to this question tend to revert to a version of the financial growth cycle model which integrates the changing financial needs and options available to entrepreneurs and the level of risk associated with their business activities (North, Baldock, and Ullah 2013). This model, the 'finance escalator', depicts sequential transitions between different types of funding that sustain business development.

There is an unresolved paradox in the finance escalator literature. On the one hand, the finance escalator is a universal model, built from pecking order and trade-off theories (Myers 1984; Berger and Udell 1998; Baldock and Mason 2015). On the other hand, empirical studies that employ the finance escalator construct tend to focus on context-specific funding gaps in the escalator and how to fill them (e.g. Owen, Deakins, and Savic 2019). Such studies investigate the sequence of sources, success measures, and the overall assessment of finance experience. This sequential view has recently been challenged, where the decline in the IPO market, the growing reliance on angel investments, and the proliferation of equity crowdfunding reshaped the finance escalator into a "bundled" form (Mason 2017). As such the sequence consists of a set of multiple sources that are being used at different stages of business development, emphasizing its susceptibility to surrounding factors.

This research takes an alternative approach, avoiding the predetermination of the finance options at the outset, thus resolving this paradox. It aims to re-consider the finance escalator model through the detailed study of entrepreneurs' funding journeys within their context. This approach is 
informed by the demand perspective provided by ten Scottish entrepreneurs, delving into motivations, and the outcomes of their funding decisions.

A growing stream of literature suggests that understanding and management of demand-side attributes are important to bridge finance gaps (Cowling et al. 2016; Cumming and Vismara 2017). Researchers suggest that entrepreneurs tend to overestimate the difficulties associated with raising finance, and seek easier ways through their close social networks first (Chemmanur and Fulghieri 2014; Klyver and Hindle 2007). Additionally, the level of risk of new ventures is unacceptably high for professional market participants due to their nature, rather than the lack of efforts to decrease uncertainty (Cassar 2004). As a result, funds from family, friends, and other non-professional (informal) funding providers are traditionally placed at the first step of the finance escalator, followed by debt, and later - equity, conforming to pecking order theory (Baldock and Mason 2015).

This view is challenged by empirical evidence that financial help from internal sources, such as family and friends, varies widely by context; for example, it is relatively rare in the UK compared with other countries (Hart, Bonner, and Levie 2016). Further, theoretical models suggest that shadow costs can significantly reduce incentives for entrepreneurs to seek such forms of funding, if alternatives are available (Lee and Persson 2016). Indeed, the extensive use of debt finance by new businesses is reported, despite the common view about the inaccessibility of bank finance due to the insufficient trading history and the lack of collateral (Small Business Survey 2017). Yet the dominant theoretical position in the literature is the preference of external equity over debt to fund ventures with growth aspirations, to avoid high leverage and maximize profitability (Hechavarría, Matthews, and Reynolds 2016). This lack of linearity and uniformity in the theory and practice of sequential financial choices of entrepreneurs lays the foundations of this research, which aims to re-visit the traditional representation of the finance escalator. 
Looking more specifically into various forms of entrepreneurial finance, the recent financial crisis has left its imprint on the financial capital market (Cumming and Vismara 2017). First, the growing reliance on a wide range of bootstrapping techniques has become a significant feature of entrepreneurial ventures, not only to handle the liability of newness, but to maximize efficiency to run a business (Winborg 2015). Second, previously hands-on independent business angels have formed syndicates, switching from a personalized approach to managing portfolios and multi-stage selective processes to increase efficiency, mitigate risks, and leverage growing demand (White and Dumay 2017; Mason, Botelho, and Harrison 2016). In contrast, the venture capital market has become populated by smaller organisations (venture capital funds) concentrated locally, thriving on the established financial infrastructure, and digital technology (Pierrakis and Saridakis 2017). Corporate venture capital has been on an upswing, feeding into business diversification strategies (Barclays 2017). Third, digitalisation, and disintermediation have disrupted not only the venture capital market, but the banking industry (peer-to-peer lending, online banking) and the venture capital market (equity crowdfunding) (Tang 2019), while making funding more affordable, but at times even more alienating for some businesses (Audretsch et al. 2016). Although still minor compared to traditional methods of finance (e.g. bank credit), these online tools have become part of the choice pool of entrepreneurs (Hart et al. 2018).

In addition to these shifts in sources of finance, there is growing evidence that entrepreneurs tend to try out multiple sources of funding in parallel rather than different sources in sequence (Hanssens, Deloof, and Vanacker 2016; Mason 2017). These changing market structures, where entrepreneurs have to adapt to obtain the resources they need, call for a dynamic approach to exploring the nature of financing decision processes. 
This approach is adopted in this paper, which seeks to answer the question: how do the internal motivations of entrepreneurs, and their perception of external drivers inform their funding decisions?

The following section reviews the evolution of the literature on the finance escalator, building an argument that the situational context of entrepreneurs are the key parameters defining choice and access to financial resources. Then, the research methodology is outlined, followed by the analysis of ten funding journeys entrepreneurs in Scotland, where patterns are identified, and articulated as themes. Finally, the findings are discussed in terms of key contributions, a proposed revised finance escalator, implications, and suggested future research avenues.

\section{The evolution of the finance escalator model}

The original representation of the finance escalator, mentioned in the work of Van Osnabrugge (2000) and further adapted by Reitan and Sorheim (2000), included four consecutive non-overlapping steps: funds from founders, friends and family, informal investors (a synonym for business angels), banks and institutional venture capital, and initial public offering. North et al. (2013) further advanced the model for technology-based small firms, where public grants at the seed (pre-trading) stage of business development constitute the initial external capital for businesses which are still too risky for both bank and equity finance. Later on, but still during the pre-trading period, entrepreneurs can reach out to professional private investors (business angels), subsequently utilising larger scale venture capital. And once the revenue income is established, lending options become possible. Yet when they compared their model to the evidence in the UK, the authors emphasized the malfunctioning of the escalator, and identified several funding gaps associated with high failure rates during the pre-trading period, a widening gap between professional private 
investors and institutional venture capital, and a greater shortage of capital for companies relying mostly on long-term equity finance. Further gaps are driven by the geographical spread of entrepreneurial activity and the supply of entrepreneurial finance. Regional variations in venture capital, public funds, bank credit, and bootstrapping strategies (Mason and Pierrakis 2013; Winborg and Landström 2001) suggest that the finance escalator looks different in different places.

Harrison (2013) noted the increasing funding gap at the commercialisation stage during the post-2010 period, when bank finance and institutional venture capital (both in the UK and US) were deferred even further along the timeline of business development (see Table 4 Analytical theme 2: the preferred versus actual sequence of finance sources

\begin{tabular}{|c|c|c|}
\hline Cases & Citations (reasoning for divergence) & Categories \\
\hline $\mathbf{A}$ & $\begin{array}{l}\text { "So, that was a really difficult period for us. We were almost at the point where we were thinking we were just not going to make it work. } \\
\text { So, we went to some family and friends that had known me from the previous life, and my professional career at ... and it was certainly not } \\
\text { our first choice, because in my experience mixing business with family and friends is fraught with danger. [...] It was a quick solution, it was } \\
\text { an easy solution, but it was certainly not done without, you know, a lot of thought and consideration to what impact it would have on our } \\
\text { personal lives.". }\end{array}$ & $\begin{array}{l}\text { Filling in gaps, fast } \\
\text { access, informal } \\
\text { funding as a last } \\
\quad \text { resort }\end{array}$ \\
\hline B & $\begin{array}{l}\text { "At one point I had more investors than I needed, so I tried to consolidate the investors, I tried to reduce the number if them. We were trying } \\
\text { to keep the ones, who were putting in more money. But my brother-in-law he wanted to invest, so I told the business angels that I didn't } \\
\text { need as much from them. [...] You have to be careful about involving family members in the business, when you've got a mixture of private } \\
\text { investors, and family and friends". }\end{array}$ & $\begin{array}{l}\text { Informal funding as a } \\
\text { second choice }\end{array}$ \\
\hline $\mathbf{C}$ & $\begin{array}{l}\text { "So, it ended up being quite a lot over the first year. So initially she was going to give me 5000, and then it was } 10000, \text { and then it was a } \\
\text { little bit extra, a little bit extra until it built up... And when I finally found the place, and I calculated exactly how much I would need, I was } \\
\text { short of a little bit. But I didn't go to anywhere else, because my mom had already a shortfall, so it was easy. " }\end{array}$ & $\begin{array}{c}\text { Filling in gaps, fast } \\
\text { access }\end{array}$ \\
\hline D & $\begin{array}{l}\text { "So I went away, I did all the list of stuff that they [banks] wanted in order to strengthen the proposition, and more, actually. And then went } \\
\text { back to them } 6 \text { months later, and } 6 \text { months later, they were even less interested than they were in the first time I went to them. Then ...like, } \\
\text { for example, there were other people who may have considered giving me money, because they [parents] had observed that I'd taken some } \\
\text { steps of being proactive... This was the last remaining option." }\end{array}$ & $\begin{array}{l}\text { Filling in gaps, } \\
\text { informal funding as a } \\
\text { last resort }\end{array}$ \\
\hline $\mathbf{E}$ & $\begin{array}{l}\text { "And then we thought how to get greedy it and to expand more and more, so we hire a lot of new staff. [...] We were under resourced for the } \\
\text { growth that we had. So, yes, those sorts of things would be some of the overheads that were emerging rapidly, and we needed fast solutions. } \\
\text { [...] I felt he [then-partner] was the best person, because he ticked those boxes of trust...." }\end{array}$ & $\begin{array}{c}\text { Filling in gaps, fast } \\
\text { access }\end{array}$ \\
\hline $\mathbf{F}$ & $\begin{array}{l}\text { "At that stage it seemed as incredibly high risk, because we didn't even have a product yet. And that makes it more difficult to get the funds } \\
\text { from institutional investors, leaving us with fewer and less attractive options... That's why we relied on a bit more the personal attach, who }\end{array}$ & $\begin{array}{l}\text { Filling in gaps, fast } \\
\text { access }\end{array}$ \\
\hline
\end{tabular}


believe into you as a person... Alternatively, I certainly would have needed to find a bit more of money from someone else. It would have possibly delayed me being able to access that smart grant fund."

"We knew from our business plan that we needed a certain amount of cash to pay for the rent, to buy computers, to buy a car, to pay for the stationary, to employ someone, to furnish the offices... But our overheads started to go pretty fast... and we needed more cash to fund it. ... and my dad saw that, and stepped in...".

"I suppose, to some extent I didn't get any cash to start-up, but I had their [parents'] contracts, and the money that I paid my parents for the business came out of the business as it traded....And I don't know if the business would have grown the way it has. And it was necessary to attract big players - institutional investors".

I "If not the [monetary] gift I got from my aunt, I would not even consider starting a business...I thought to put it to a good use. I would not even go to the bank if not the realisation of the responsibility that I need to do it properly..."

"Other options would have possibly delayed us [...] we did not like the idea sharing equity, and it would have meant...well, it would have taken quite a bit longer... And a friend of ours shared this idea with us [crowdfunding], and we thought - why not!".

\begin{tabular}{|c|}
\hline $\begin{array}{c}\text { Filling in gaps, fast } \\
\text { access }\end{array}$ \\
\hline $\begin{array}{c}\text { Informal funding as a } \\
\text { stepping stone }\end{array}$ \\
\hline $\begin{array}{c}\text { Informal funding as a } \\
\text { stepping stone }\end{array}$ \\
\hline $\begin{array}{c}\text { Filling in gaps, fast } \\
\text { access }\end{array}$ \\
\hline
\end{tabular}




\begin{tabular}{|c|c|c|}
\hline Cases & Citations (sources of dynamism in decision-making) & Categories \\
\hline A & $\begin{array}{l}\text { "I mean, that [pitching for equity investment] was unsuccessful for a couple of reasons. I think we were underprepared. I think, the format } \\
\text { of the meeting was unsuitable. And they put us in the room with five individuals who didn't know each other. So, it wasn't a very easy } \\
\text { environment for pitching for money. [...] Then the petrol costs had grown up, the value of the pound went down, the margins on the } \\
\text { international basis went down. [...] We just lost } 20 \% \text { margin on based nothing rather than currency!" }\end{array}$ & $\begin{array}{l}\text { Unpreparedness as an } \\
\text { internal factor, } \\
\text { recession as an external } \\
\text { factor }\end{array}$ \\
\hline B & $\begin{array}{l}\text { "So we've only, may be got about 5-6 months what's the funding left in the business. And if we don't raise more investment then, I think, } \\
\text { we'll be out of business. [...] We've not had a sales team in our business. I don't think the product is the right product for the retail } \\
\text { market. I don't think we've got the merchandising right. I don't think the price point of the retail product is correct. I think, we've had } \\
\text { difficulties with our supply chain. And we're not making enough of the profit margin on the sales that we do make". }\end{array}$ & $\begin{array}{l}\text { The need for further } \\
\text { business development }\end{array}$ \\
\hline $\mathbf{C}$ & $\begin{array}{l}\text { "I just looked around and checked what was available out there locally [...]. I didn't really do any business side of the school. I was just } \\
\text { teaching, and organizing the staff, and appearance, and everything. But I didn't have any financial responsibility. And that was a lot of } \\
\text { learning, very quickly. Because I think...I was so passionate about what I do, that I was, may be, too positive about everything in the } \\
\text { beginning". }\end{array}$ & $\begin{array}{l}\text { Local infrastructure, } \\
\text { lack of expertise }\end{array}$ \\
\hline $\mathbf{D}$ & $\begin{array}{l}\text { "This was 2009-2010, so it was a very difficult thing to get money from the banks. If I'd done it in 2005-2006, they probably would have } \\
\text { just given me money. I tried once, but I wouldn't try more at that time..." }\end{array}$ & $\begin{array}{l}\text { Recession } \\
\text { external }\end{array}$ \\
\hline $\mathbf{E}$ & $\begin{array}{l}\text { "Again, the biggest thing that was hit during the recession. Obviously in } 2000, \text { we started in July, and in September } 2000 \text { there was that } \\
\text { downturn in the economy, we all thought it was the recession time, but we now know that it wasn't! [...] we, probably, would have } \\
\text { struggled to find finance in 2000, when the economy was bad, and during the last recession...". }\end{array}$ & $\begin{array}{l}\text { Recession as an } \\
\text { external factor }\end{array}$ \\
\hline $\mathbf{F}$ & $\begin{array}{l}\text { "Interacting with people, making sure that you can delegate your tasks to the right people, and then manage that, and make sure that the } \\
\text { people work for you and with you as a team, and deliver to your expectations. So, it's a different skill set. It requires a lot of } \\
\text { communication, a lot of structure... And I'm still learning that, you know... I'm still growing into this new role of becoming the managing } \\
\text { director. And then, unfortunately, the huge financial collapse happened, global recession, and that meant that there was simply no money } \\
\text { anywhere. And that was incredibly difficult, because...I needed money" }\end{array}$ & $\begin{array}{l}\text { Lack of expertise, } \\
\text { recession as an external } \\
\text { factor }\end{array}$ \\
\hline $\mathbf{G}$ & $\begin{array}{l}\text { "We didn't really worry about the economic situation, because there was a demand for recruitment company. There was a gap in the } \\
\text { market for a good recruitment company. We took it...it was difficult, it was a downturn, but nothing that affected us significantly. And the } \\
\text { market was going up... Probably, we could have gone more quickly, but we went quickly anyway". }\end{array}$ & $\begin{array}{l}\text { Recession as an } \\
\text { external factor }\end{array}$ \\
\hline $\mathbf{H}$ & $\begin{array}{l}\text { "It's more circumstances that anything else. But I think it's quite normal for people... there was a formal valuation done, but was very } \\
\text { informal how the money came in as the recession hit, and the prices fell down..." }\end{array}$ & $\begin{array}{l}\text { Recession as an } \\
\text { external factor }\end{array}$ \\
\hline I & "I just went to my local branch, as I had already got an account with them..." & Convenience \\
\hline $\mathbf{J}$ & $\begin{array}{l}\text { "We weren't really ready to invest more time into paperwork, as we have already started out classes... And then a friend of ours invited us } \\
\text { to this event just around the corner, where we met X - the founder of } Y \text { [an online crowdfunding platform]". }\end{array}$ & $\begin{array}{c}\text { Local networking } \\
\text { opportunities }\end{array}$ \\
\hline
\end{tabular}


Figure 1). The rapid growth of crowdfunding, microfinance, and peer-to-peer lending mechanisms in recent years partly addressed these finance gaps for starting and growing ventures (Bruton et al. 2015). Later, they were further effectively filled in by government equity schemes (Baldock and Mason 2015). Bootstrapping, and consistent government interventions in the market for human capital, networks, and access to information, laid the financial pathway for innovative fast-growing businesses in the most recent years, covering the retreat of banking finance (Owen, Deakins, and Savic 2019).

\section{[Insert Table 4 Analytical theme 2: the preferred versus actual sequence of finance sources}

\begin{tabular}{|c|c|c|}
\hline Cases & Citations (reasoning for divergence) & Categories \\
\hline $\mathbf{A}$ & $\begin{array}{l}\text { "So, that was a really difficult period for us. We were almost at the point where we were thinking we were just not going to make it work. } \\
\text { So, we went to some family and friends that had known me from the previous life, and my professional career at ... and it was certainly not } \\
\text { our first choice, because in my experience mixing business with family and friends is fraught with danger. [...] It was a quick solution, it was } \\
\text { an easy solution, but it was certainly not done without, you know, a lot of thought and consideration to what impact it would have on our } \\
\text { personal lives.". }\end{array}$ & $\begin{array}{l}\text { Filling in gaps, fast } \\
\text { access, informal } \\
\text { funding as a last } \\
\text { resort }\end{array}$ \\
\hline $\mathbf{B}$ & $\begin{array}{l}\text { "At one point I had more investors than I needed, so I tried to consolidate the investors, I tried to reduce the number if them. We were trying } \\
\text { to keep the ones, who were putting in more money. But my brother-in-law he wanted to invest, so I told the business angels that I didn't } \\
\text { need as much from them. [...] You have to be careful about involving family members in the business, when you've got a mixture of private } \\
\text { investors, and family and friends". }\end{array}$ & $\begin{array}{l}\text { Informal funding as a } \\
\text { second choice }\end{array}$ \\
\hline $\mathbf{C}$ & $\begin{array}{l}\text { "So, it ended up being quite a lot over the first year. So initially she was going to give me 5000, and then it was } 10000, \text { and then it was a } \\
\text { little bit extra, a little bit extra until it built up... And when I finally found the place, and I calculated exactly how much I would need, I was } \\
\text { short of a little bit. But I didn't go to anywhere else, because my mom had already a shortfall, so it was easy." }\end{array}$ & $\begin{array}{l}\text { Filling in gaps, fast } \\
\text { access }\end{array}$ \\
\hline $\mathbf{D}$ & $\begin{array}{l}\text { "So I went away, I did all the list of stuff that they [banks] wanted in order to strengthen the proposition, and more, actually. And then went } \\
\text { back to them } 6 \text { months later, and } 6 \text { months later, they were even less interested than they were in the first time I went to them. Then ...like, } \\
\text { for example, there were other people who may have considered giving me money, because they [parents] had observed that I'd taken some } \\
\text { steps of being proactive... This was the last remaining option." }\end{array}$ & $\begin{array}{l}\text { Filling in gaps, } \\
\text { informal funding as a } \\
\text { last resort }\end{array}$ \\
\hline $\mathbf{E}$ & $\begin{array}{l}\text { "And then we thought how to get greedy it and to expand more and more, so we hire a lot of new staff. [...] We were under resourced for the } \\
\text { growth that we had. So, yes, those sorts of things would be some of the overheads that were emerging rapidly, and we needed fast solutions. } \\
\text { [...] I felt he [then-partner] was the best person, because he ticked those boxes of trust...." }\end{array}$ & $\begin{array}{l}\text { Filling in gaps, fast } \\
\text { access }\end{array}$ \\
\hline $\mathbf{F}$ & $\begin{array}{l}\text { "At that stage it seemed as incredibly high risk, because we didn't even have a product yet. And that makes it more difficult to get the funds } \\
\text { from institutional investors, leaving us with fewer and less attractive options... That's why we relied on a bit more the personal attach, who }\end{array}$ & $\begin{array}{l}\text { Filling in gaps, fast } \\
\text { access }\end{array}$ \\
\hline
\end{tabular}


believe into you as a person... Alternatively, I certainly would have needed to find a bit more of money from someone else. It would have possibly delayed me being able to access that smart grant fund."

"We knew from our business plan that we needed a certain amount of cash to pay for the rent, to buy computers, to buy a car, to pay for the stationary, to employ someone, to furnish the offices... But our overheads started to go pretty fast... and we needed more cash to fund it. ... and my dad saw that, and stepped in...".

"I suppose, to some extent I didn't get any cash to start-up, but I had their [parents'] contracts, and the money that I paid my parents for the business came out of the business as it traded....And I don't know if the business would have grown the way it has. And it was necessary to attract big players - institutional investors".

I "If not the [monetary] gift I got from my aunt, I would not even consider starting a business...I thought to put it to a good use. I would not even go to the bank if not the realisation of the responsibility that I need to do it properly..."

"Other options would have possibly delayed us [...] we did not like the idea sharing equity, and it would have meant...well, it would have taken quite a bit longer... And a friend of ours shared this idea with us [crowdfunding], and we thought - why not!".

\begin{tabular}{|c|}
\hline $\begin{array}{c}\text { Filling in gaps, fast } \\
\text { access }\end{array}$ \\
\hline $\begin{array}{c}\text { Informal funding as a } \\
\text { stepping stone }\end{array}$ \\
\hline $\begin{array}{c}\text { Informal funding as a } \\
\text { stepping stone }\end{array}$ \\
\hline $\begin{array}{c}\text { Filling in gaps, fast } \\
\text { access }\end{array}$ \\
\hline
\end{tabular}




\begin{tabular}{|c|c|c|}
\hline Cases & Citations (sources of dynamism in decision-making) & Categories \\
\hline A & $\begin{array}{l}\text { "I mean, that [pitching for equity investment] was unsuccessful for a couple of reasons. I think we were underprepared. I think, the format } \\
\text { of the meeting was unsuitable. And they put us in the room with five individuals who didn't know each other. So, it wasn't a very easy } \\
\text { environment for pitching for money. [...] Then the petrol costs had grown up, the value of the pound went down, the margins on the } \\
\text { international basis went down. [...] We just lost } 20 \% \text { margin on based nothing rather than currency!" }\end{array}$ & $\begin{array}{l}\text { Unpreparedness as an } \\
\text { internal factor, } \\
\text { recession as an external } \\
\text { factor }\end{array}$ \\
\hline B & $\begin{array}{l}\text { "So we've only, may be got about 5-6 months what's the funding left in the business. And if we don't raise more investment then, I think, } \\
\text { we'll be out of business. [...] We've not had a sales team in our business. I don't think the product is the right product for the retail } \\
\text { market. I don't think we've got the merchandising right. I don't think the price point of the retail product is correct. I think, we've had } \\
\text { difficulties with our supply chain. And we're not making enough of the profit margin on the sales that we do make". }\end{array}$ & $\begin{array}{l}\text { The need for further } \\
\text { business development }\end{array}$ \\
\hline $\mathbf{C}$ & $\begin{array}{l}\text { "I just looked around and checked what was available out there locally [...]. I didn't really do any business side of the school. I was just } \\
\text { teaching, and organizing the staff, and appearance, and everything. But I didn't have any financial responsibility. And that was a lot of } \\
\text { learning, very quickly. Because I think...I was so passionate about what I do, that I was, may be, too positive about everything in the } \\
\text { beginning". }\end{array}$ & $\begin{array}{l}\text { Local infrastructure, } \\
\text { lack of expertise }\end{array}$ \\
\hline $\mathbf{D}$ & $\begin{array}{l}\text { "This was 2009-2010, so it was a very difficult thing to get money from the banks. If I'd done it in 2005-2006, they probably would have } \\
\text { just given me money. I tried once, but I wouldn't try more at that time..." }\end{array}$ & $\begin{array}{l}\text { Recession } \\
\text { external }\end{array}$ \\
\hline $\mathbf{E}$ & $\begin{array}{l}\text { "Again, the biggest thing that was hit during the recession. Obviously in } 2000, \text { we started in July, and in September } 2000 \text { there was that } \\
\text { downturn in the economy, we all thought it was the recession time, but we now know that it wasn't! [...] we, probably, would have } \\
\text { struggled to find finance in 2000, when the economy was bad, and during the last recession...". }\end{array}$ & $\begin{array}{l}\text { Recession as an } \\
\text { external factor }\end{array}$ \\
\hline $\mathbf{F}$ & $\begin{array}{l}\text { "Interacting with people, making sure that you can delegate your tasks to the right people, and then manage that, and make sure that the } \\
\text { people work for you and with you as a team, and deliver to your expectations. So, it's a different skill set. It requires a lot of } \\
\text { communication, a lot of structure... And I'm still learning that, you know... I'm still growing into this new role of becoming the managing } \\
\text { director. And then, unfortunately, the huge financial collapse happened, global recession, and that meant that there was simply no money } \\
\text { anywhere. And that was incredibly difficult, because...I needed money" }\end{array}$ & $\begin{array}{l}\text { Lack of expertise, } \\
\text { recession as an external } \\
\text { factor }\end{array}$ \\
\hline $\mathbf{G}$ & $\begin{array}{l}\text { "We didn't really worry about the economic situation, because there was a demand for recruitment company. There was a gap in the } \\
\text { market for a good recruitment company. We took it...it was difficult, it was a downturn, but nothing that affected us significantly. And the } \\
\text { market was going up... Probably, we could have gone more quickly, but we went quickly anyway". }\end{array}$ & $\begin{array}{l}\text { Recession as an } \\
\text { external factor }\end{array}$ \\
\hline $\mathbf{H}$ & $\begin{array}{l}\text { "It's more circumstances that anything else. But I think it's quite normal for people... there was a formal valuation done, but was very } \\
\text { informal how the money came in as the recession hit, and the prices fell down..." }\end{array}$ & $\begin{array}{l}\text { Recession as an } \\
\text { external factor }\end{array}$ \\
\hline I & "I just went to my local branch, as I had already got an account with them..." & Convenience \\
\hline $\mathbf{J}$ & $\begin{array}{l}\text { "We weren't really ready to invest more time into paperwork, as we have already started out classes... And then a friend of ours invited us } \\
\text { to this event just around the corner, where we met X - the founder of } Y \text { [an online crowdfunding platform]". }\end{array}$ & $\begin{array}{c}\text { Local networking } \\
\text { opportunities }\end{array}$ \\
\hline
\end{tabular}




\section{Figure 1 about here]}

\section{Factors underpinning finance choice: multi-layered embeddedness}

Moving from the two-dimensional representation of the finance escalator depicted in Table 4 Analytical theme 2: the preferred versus actual sequence of finance sources

\begin{tabular}{|c|c|c|}
\hline Cases & Citations (reasoning for divergence) & Categories \\
\hline $\mathbf{A}$ & $\begin{array}{l}\text { "So, that was a really difficult period for us. We were almost at the point where we were thinking we were just not going to make it work. } \\
\text { So, we went to some family and friends that had known me from the previous life, and my professional career at ... and it was certainly not } \\
\text { our first choice, because in my experience mixing business with family and friends is fraught with danger. [...] It was a quick solution, it was } \\
\text { an easy solution, but it was certainly not done without, you know, a lot of thought and consideration to what impact it would have on our } \\
\text { personal lives.". }\end{array}$ & $\begin{array}{l}\text { Filling in gaps, fast } \\
\text { access, informal } \\
\text { funding as a last } \\
\text { resort }\end{array}$ \\
\hline B & $\begin{array}{l}\text { "At one point I had more investors than I needed, so I tried to consolidate the investors, I tried to reduce the number if them. We were trying } \\
\text { to keep the ones, who were putting in more money. But my brother-in-law he wanted to invest, so I told the business angels that I didn't } \\
\text { need as much from them. [...] You have to be careful about involving family members in the business, when you've got a mixture of private } \\
\text { investors, and family and friends". }\end{array}$ & $\begin{array}{l}\text { Informal funding as a } \\
\text { second choice }\end{array}$ \\
\hline $\mathbf{C}$ & $\begin{array}{l}\text { "So, it ended up being quite a lot over the first year. So initially she was going to give me 5000, and then it was } 10000, \text { and then it was a } \\
\text { little bit extra, a little bit extra until it built up... And when I finally found the place, and I calculated exactly how much I would need, I was } \\
\text { short of a little bit. But I didn't go to anywhere else, because my mom had already a shortfall, so it was easy." }\end{array}$ & $\begin{array}{l}\text { Filling in gaps, fast } \\
\text { access }\end{array}$ \\
\hline D & $\begin{array}{l}\text { "So I went away, I did all the list of stuff that they [banks] wanted in order to strengthen the proposition, and more, actually. And then went } \\
\text { back to them } 6 \text { months later, and } 6 \text { months later, they were even less interested than they were in the first time I went to them. Then ...like, } \\
\text { for example, there were other people who may have considered giving me money, because they [parents] had observed that I'd taken some } \\
\text { steps of being proactive... This was the last remaining option." }\end{array}$ & $\begin{array}{l}\text { Filling in gaps, } \\
\text { informal funding as a } \\
\text { last resort }\end{array}$ \\
\hline $\mathbf{E}$ & $\begin{array}{l}\text { "And then we thought how to get greedy it and to expand more and more, so we hire a lot of new staff. [...] We were under resourced for the } \\
\text { growth that we had. So, yes, those sorts of things would be some of the overheads that were emerging rapidly, and we needed fast solutions. } \\
\text { [...] I felt he [then-partner] was the best person, because he ticked those boxes of trust...." }\end{array}$ & $\begin{array}{l}\text { Filling in gaps, fast } \\
\text { access }\end{array}$ \\
\hline $\mathbf{F}$ & $\begin{array}{l}\text { "At that stage it seemed as incredibly high risk, because we didn't even have a product yet. And that makes it more difficult to get the funds } \\
\text { from institutional investors, leaving us with fewer and less attractive options... That's why we relied on a bit more the personal attach, who } \\
\text { believe into you as a person... Alternatively, I certainly would have needed to find a bit more of money from someone else. It would have } \\
\text { possibly delayed me being able to access that smart grant fund." }\end{array}$ & $\begin{array}{l}\text { Filling in gaps, fast } \\
\text { access }\end{array}$ \\
\hline
\end{tabular}


"We knew from our business plan that we needed a certain amount of cash to pay for the rent, to buy computers, to buy a car, to pay for the and my dad saw that, and stepped in...".

"I suppose, to some extent I didn't get any cash to start-up, but I had their [parents'] contracts, and the money that I paid my parents for the business came out of the business as it traded....And I don't know if the business would have grown the way it has. And it was necessary to attract big players - institutional investors".

I "If not the [monetary] gift I got from my aunt, I would not even consider starting a business...I thought to put it to a good use. I would not even go to the bank if not the realisation of the responsibility that I need to do it properly....

taken quite a bit longer... And a friend of ours shared this idea with us [crowdfunding], and we thought - why not!".

Filling in gaps, fast access

Informal funding as a stepping stone

Informal funding as a stepping stone

Filling in gaps, fast access 


\begin{tabular}{|c|c|c|}
\hline Cases & Citations (sources of dynamism in decision-making) & Categories \\
\hline A & $\begin{array}{l}\text { "I mean, that [pitching for equity investment] was unsuccessful for a couple of reasons. I think we were underprepared. I think, the format } \\
\text { of the meeting was unsuitable. And they put us in the room with five individuals who didn't know each other. So, it wasn't a very easy } \\
\text { environment for pitching for money. [...] Then the petrol costs had grown up, the value of the pound went down, the margins on the } \\
\text { international basis went down. [...] We just lost } 20 \% \text { margin on based nothing rather than currency!" }\end{array}$ & $\begin{array}{l}\text { Unpreparedness as an } \\
\text { internal factor, } \\
\text { recession as an external } \\
\text { factor }\end{array}$ \\
\hline B & $\begin{array}{l}\text { "So we've only, may be got about 5-6 months what's the funding left in the business. And if we don't raise more investment then, I think, } \\
\text { we'll be out of business. [...] We've not had a sales team in our business. I don't think the product is the right product for the retail } \\
\text { market. I don't think we've got the merchandising right. I don't think the price point of the retail product is correct. I think, we've had } \\
\text { difficulties with our supply chain. And we're not making enough of the profit margin on the sales that we do make". }\end{array}$ & $\begin{array}{l}\text { The need for further } \\
\text { business development }\end{array}$ \\
\hline $\mathbf{C}$ & $\begin{array}{l}\text { "I just looked around and checked what was available out there locally [...]. I didn't really do any business side of the school. I was just } \\
\text { teaching, and organizing the staff, and appearance, and everything. But I didn't have any financial responsibility. And that was a lot of } \\
\text { learning, very quickly. Because I think...I was so passionate about what I do, that I was, may be, too positive about everything in the } \\
\text { beginning". }\end{array}$ & $\begin{array}{l}\text { Local infrastructure, } \\
\text { lack of expertise }\end{array}$ \\
\hline $\mathbf{D}$ & $\begin{array}{l}\text { "This was 2009-2010, so it was a very difficult thing to get money from the banks. If I'd done it in 2005-2006, they probably would have } \\
\text { just given me money. I tried once, but I wouldn't try more at that time..." }\end{array}$ & $\begin{array}{l}\text { Recession } \\
\text { external }\end{array}$ \\
\hline $\mathbf{E}$ & $\begin{array}{l}\text { "Again, the biggest thing that was hit during the recession. Obviously in } 2000, \text { we started in July, and in September } 2000 \text { there was that } \\
\text { downturn in the economy, we all thought it was the recession time, but we now know that it wasn't! [...] we, probably, would have } \\
\text { struggled to find finance in 2000, when the economy was bad, and during the last recession...". }\end{array}$ & $\begin{array}{l}\text { Recession as an } \\
\text { external factor }\end{array}$ \\
\hline $\mathbf{F}$ & $\begin{array}{l}\text { "Interacting with people, making sure that you can delegate your tasks to the right people, and then manage that, and make sure that the } \\
\text { people work for you and with you as a team, and deliver to your expectations. So, it's a different skill set. It requires a lot of } \\
\text { communication, a lot of structure... And I'm still learning that, you know... I'm still growing into this new role of becoming the managing } \\
\text { director. And then, unfortunately, the huge financial collapse happened, global recession, and that meant that there was simply no money } \\
\text { anywhere. And that was incredibly difficult, because...I needed money" }\end{array}$ & $\begin{array}{l}\text { Lack of expertise, } \\
\text { recession as an external } \\
\text { factor }\end{array}$ \\
\hline $\mathbf{G}$ & $\begin{array}{l}\text { "We didn't really worry about the economic situation, because there was a demand for recruitment company. There was a gap in the } \\
\text { market for a good recruitment company. We took it...it was difficult, it was a downturn, but nothing that affected us significantly. And the } \\
\text { market was going up... Probably, we could have gone more quickly, but we went quickly anyway". }\end{array}$ & $\begin{array}{l}\text { Recession as an } \\
\text { external factor }\end{array}$ \\
\hline $\mathbf{H}$ & $\begin{array}{l}\text { "It's more circumstances that anything else. But I think it's quite normal for people... there was a formal valuation done, but was very } \\
\text { informal how the money came in as the recession hit, and the prices fell down..." }\end{array}$ & $\begin{array}{l}\text { Recession as an } \\
\text { external factor }\end{array}$ \\
\hline I & "I just went to my local branch, as I had already got an account with them..." & Convenience \\
\hline $\mathbf{J}$ & $\begin{array}{l}\text { "We weren't really ready to invest more time into paperwork, as we have already started out classes... And then a friend of ours invited us } \\
\text { to this event just around the corner, where we met X - the founder of } Y \text { [an online crowdfunding platform]". }\end{array}$ & $\begin{array}{c}\text { Local networking } \\
\text { opportunities }\end{array}$ \\
\hline
\end{tabular}


Figure 1, the funding choice is not only a function of the stage of business development and the risk associated with the venture, but also depends on a range of venture attributes that can unlock different financial sources. Examples include: business type, business location, track record, past experience, preparation and research, pitching abilities of an entrepreneur, and others (e.g. Kotha and George 2012; Jeffrey, Lévesque, and Maxwell 2016). Studies such as these tend to focus on specific sources (either bank loans or venture capital), when seeking relationships between individual-level factors and funding success. However, given the wide range of potential funding mechanisms, information asymmetries, and uncertainty surrounding the potential of a new business, a more holistic approach is necessary, one that acknowledges the unique way in which each entrepreneur is embedded in their surroundings (Welter 2011).

It has been consistently shown that entrepreneurial behaviour is inherently linked to its social context, where one influences another in a mutual way through a constant process of adaptation and change (Dacin, Ventresca, and Beal 1999; Welter 2011; Welter and Smallbone 2011). This context has an effect on multiple aspects of entrepreneurial activity, starting from forming an intention to start a business and mobilizing resources, to its subsequent development (Shane 2003; Martinelli 2004). The investigation of this relationship with the environment originates in institutional theory, where the emergence and development of institutions enable entrepreneurs to deal with uncertainty and mitigate risks associated with the external environment, from one side, and from the other side deal with the barriers imposed by them, consequently driving further institutional change in the economy (North 1990; Welter 2011). In other words, entrepreneurs tend to adjust their behaviour to accommodate contextual constraints, and grasp opportunities, thus, consequently, leading to changes in the context itself.

In this view, the process of obtaining finance is reliant on its accessibility and availability, imposed to a large extent by the external environment, thus prompting entrepreneurs to form 
certain behavioural characteristics in response to that, such as 'financial bootstrapping' and 'networking' in the situation when formal finance and other forms of capital are scarce (Welter and Smallbone 2011). This interaction with the external environment gives rise, for example, to the 'formalization' of networking mechanisms to enable access to resources for certain types of entrepreneurs (e.g. crowdfunding and peer-to-peer lending). This illustrates the impact of the embeddedness of entrepreneurship in its social, spatial, and institutional contexts, starting from leveraging the benefits of a particular social circle and locale, and finally introducing new market mechanisms.

When considering entrepreneurial behaviour, a holistic approach to context, so-called omnibus context, is useful in grasping its multiple dimensions, levels of analysis, and interactions across them (Griffin 2007). In particular, 1) the social dimension of context is important at an individual level as it brings benefits and challenges imposed by social networks; 2) the spatial dimension connects entrepreneurs with communities and business infrastructure locally; and 3) the institutional dimension encompasses political and economic rules, and informal mechanisms binding all levels. Each of these dimensions are explored further in succeeding sub-sections.

\section{1) Social embeddedness}

The most common application of the social dimension of context to entrepreneurial behaviours is made through the social network perspective, where entrepreneurs are tied through social relationships and embedded into networks (Jack and Anderson 2002). From this perspective, structural embeddedness not only represents social complexity, where entrepreneurs face competing pressures imposed by economic and social realities, but also the use of ties to obtain resources (Uzzi 1997, 1999). Moreover, the process of becoming part of particular social structures enables entrepreneurs to use embeddedness purposefully to extract value (Jack and 
Anderson 2002). As a result, the structure of the social context, the integration process, and the interactions within it expose entrepreneurs to opportunities, and constraints, associated mainly with tensions between social and economic motives. How entrepreneurs navigate these tensions can affect their ability to draw on resources and thus develop their venture (McKeever, Jack, and Anderson 2015).

For example, it is asserted that to obtain resources, one should reach out to weaker social ties, as they provide an access to a wider network and contact resources (Marsden and Hurlbert 1988). However, researchers argue that at the early business development stage, an entrepreneur's personal networks are synonymous with their organisational networks (Hite and Hesterly 2001), and new business owners are characterized by a help-seeking behaviour driven by close relational proximity (Bird and Zellweger 2018). Thus they are more likely to seek help from their close social networks, such as friends and family, as the costs of search, negotiation, and potential rejection are minimal (Larson and Starr 1993). Additionally, in times of uncertainty or urgency, individuals tend to rely on someone with whom they have been in an exchange relationship previously, as trust has already been established (Gulati 1995).

The alternative view postulates that close social ties constrain potential benefits, and therefore entrepreneurs need to reach out to more distant networks, and work on overcoming structural holes to gain desired resources and associated competitive advantage (Burt 1997). Moreover, cognitive biases of an entrepreneur (such as overconfidence, illusion of control, and representativeness) can be reinforced by reliance on a dense social network with strong ties (De Carolis and Saparito 2006). This suggests that not only can close family and friends influence an entrepreneur's actions and decisions, but the opposite takes place as well, highlighting the recursive links across dimensions, including responses to wider spatial and institutional triggers discussed below. 


\section{2) Spatial embeddedness}

This dimension encompasses the topographical, geographical, and infrastructural elements along with the entrepreneurship culture attached to a location (Korsgaard, Ferguson, and Gaddefors 2015). In a broader sense, a particular location can be described in terms of space, which relates to its economic value (i.e. the flow of capital, labour, resources, and information), and place, associated with lived experiences (Cresswell 2006). In both cases the spatial embeddedness provides entrepreneurs with resource endowments, including community resources, and intangible assets associated with a particular location (Müller and Korsgaard 2018). The former is particularly attributable to entrepreneurship in disadvantaged areas, characterised by scarcity of resources (Marshall 2004). As result, an individual response to the local-level factors occurs in a two-way direction, where an entrepreneur can influence/manage their space and place to their advantage. This interaction happens within social/cognitive boundaries of local communities, facilitating the formation of local-level institutions that ultimately drive decisions and behaviours at the individual level.

\section{3) Institutional embeddedness}

The institutional context encompasses the economic, political, and cultural environment in which entrepreneurs operate (Welter and Smallbone 2011). Regulative, normative, and cognitive elements of this context either enable entrepreneurs to exploit the resources, or pose constraints and risks associated with the access to capital (Cleaver 2001). Institutional conditions, forming part of context, are recognized to have an impact on the accumulation of entrepreneurial activity (Boettke and Coyne 2009), ultimately leading to increased investment in human and social capital (Levie and Autio 2011).

Following institutional theory, any activity is embedded in economic, social, political, and cultural arrangements, which determine the collective understanding of rules and set out a pool of choices available to actors (Dacin, Goodstein, and Scott 2002). These arrangements are a 
two-way street, as they can either create new opportunities, or impose barriers. The argument of Desa (2012) about institutional transformation through bricolage highlights how entrepreneurial behaviour can confront institutional environments and balance institutional gaps. Institutions not only impose constraints, or facilitate actions; they play a key role in forming attitudes and beliefs (Meek, Pacheco, and York 2010).

Embeddedness as a notion of belongingness to a particular context (social, spatial, or institutional) reflects the integration with and reliance on its tangible infrastructure, resources, and networks, as well as affiliation with its meanings, experiences, and heritage around entrepreneurial processes (Welter 2011). In contrast, bridging is known as an extension of ties outside of a particular known context to gain access to additional resources and opportunities (Burt 2000, 2004; Korsgaard, Ferguson, and Gaddefors 2015). Bridging structural holes, arising from the limitations of a particular context, happens not only across social networks (Burt 2000, 2004), but also across spatial dimensions (Korsgaard, Ferguson, and Gaddefors 2015), and institutional contexts (Yang 2004). As such, movements and connections are observed across all dimensions (Anderson, Drakopoulou Dodd, and Jack 2012), depending on the type of structural hole, and opportunistic vision and needs of an entrepreneur, thus revealing a dynamic nature of embeddedness (Anderson and Ronteau 2017; Wigren-Kristofersen et al. 2019) with which entrepreneurs engage and form relations (Gaddefors and Anderson 2019) to enable their activities, including access to resources.

In this paper, a multi-layered embeddedness perspective is combined with the individual perspectives of entrepreneurs in relation to their funding journeys with the purpose of capturing the dynamism and recursive links across contextual dimensions of funding decisions. Following recent transformations in the entrepreneurial finance market, this theoretical understanding calls for a dynamic approach to the finance escalator, reflecting its context-dependence, and the non-linearity of decisions. To illustrate how multi-layered 
embeddedness perspective is incorporated into the paper's research design to achieve this goal, the methodology is described in the next section.

\section{Methodology}

The interpretivist approach was adopted in this study with the aim of establishing meaning from the view of the participants, to identify shared patterns, and explore the range of perspectives, experiences, and judgements (Creswell 2013). It enables researchers to establish a holistic picture and fully understand the phenomenon (Leech and Onwuegbuzie 2007), as well as capture rich, and contextualized information centred on lived experiences (Miles and Huberman 1994).

A multiple case study design with theoretical sampling was used, as suggested by Eisenhardt and Graebner (2007), to account for the diversity of data sources, and ensure replication logic. The theoretical sample was drawn from the population of non-financial businesses in Scotland. The boundaries of the theoretical sample were defined so as to increase its heterogeneity using a variation sampling technique (Strauss and Corbin, 1990) in order to generate a diverse group of cases and recognize various contexts (at individual and spatial levels). The unit of analysis is an entrepreneur, defined as someone who is over 18 years old, and is an active owner manager of the business that has paid wages or salaries for more than three months, or who has discontinued their business in the last 12 months. To qualify for the theoretical sample, business owners should have sought any form of both informal and formal external finance at any stage of the business development, where informal funding comprised money from family, friends, or other private non-professional investors, including rewardbased crowdfunding platforms. This condition ensured comparability with the finance escalator model so that all potential funding sources are represented. Based on the initial interviews, further criteria were elaborated to achieve heterogeneity of cases across the following criteria: 
business type, business age, the stage of business development, the use of finance sources, and location (in terms of lower layer output area).

\section{Data collection}

An open sampling procedure (Strauss and Corbin 1990), incorporating snowball and networking sampling methods (Collis and Hussey 2014), was used between July 2012 and September 2013 in Scotland. In the first stage, 'gatekeeping' organisations were identified and face-to-face meetings with key people were arranged to seek references to business owners who might potentially comply with the sampling criteria. Afterwards, if the participant agreed to take part in the investigation, further arrangements were made for data collection.

A variety of information sources were employed to collect different types of data in order to contextualize the deals, verify facts through triangulation, and explore alternative perspectives. Semi-structured face-to-face interviews of at most 60 minutes long in a natural setting (either company's office or participant's house) was the core data source (Yin 2009; Brinkmann 2014). To facilitate the interview process and ensure consistency, an interview guide informed by the theoretical literature was developed (see Table 1). This information was complemented with company documentation provided by the participants to evidence the arrangements, financial indicators, and other relevant facts. It was further triangulated based on registration information and financial statements from Companies House (the UK business registration office). To understand the scope of the business activity and its progress, and verify certain operational aspects company, websites and related news items in media sources were screened. 


\section{Theoretical sample description}

As a result, 14 entrepreneurs were identified, however, only ten were used for the purpose of this study, so that variation among the cases was achieved across the pre-defined parameters, as can be seen from 
Table 2. All the entrepreneurs in the theoretical sample referred to external finance in some form (including family, friends, individuals who are not professional funders, and crowdfunding) in various arrangements (loan, equity, or donation). All the ventures were registered and operated in the major Scottish cities (Glasgow, Edinburgh, and Aberdeen), but varied in terms of local area deprivation. Moreover, the companies were launched during different phases of the economic cycle. Companies $\mathrm{G}$ and $\mathrm{H}$ survived two economic recessions, and emerged with positive financial balances. Four ventures were founded during the upward economic trend, whereas $\mathrm{B}, \mathrm{D}$, and $\mathrm{J}$ were started right after the recession hit bottom in the fourth quarter of 2008.

\section{[Insert}




\section{Table 2 about here]}

The cases represent secondary (B and F), tertiary (A, D, I, and J) and quaternary sectors (C, E, G, and H), reflective of a developed, services-oriented economy (Kenessey 1987). Most of the ventures qualified as "small" according to the Companies Act (Companies Act 2006), and had certain exemptions from audit. Their profit and loss accounts were retrieved, where available, for the period 2008-2014. Company A had not managed to launch its sales, and became officially dormant in 2011. Company $\mathbf{J}$ ceased trading in 2017 after 5 years of unprofitable operations. Companies B, C, and F were experiencing increased losses in recent years. Company D demonstrated remarkable growth in the past three years, whereas the rest had steady revenues. As a result, the selected cases conform to the criteria set for the theoretical sample: to achieve a variety in terms of company parameters. Moreover, the impact of the context can also be identified both at the local and macroeconomic levels.

\section{Data analysis}

Given the intrinsic social nature of financial decisions, an abduction logic was applied in data analysis (Dubois and Gadde 2002), where data collection and analysis build dynamically, allowing for new concepts to emerge, be compared, referred back to theory, and then related again to new cases. As a result, grounded theory, proposed in the work of Corbin and Strauss (2008), i.e. the version of the theory which deviates from the original version which refused any use of literature prior to data collection (Glaser and Strauss 1967), is used for analysis purposes, following the guidelines of Mäkelä and Turcan (2007).

The data analysis process started with data transcription and cleaning, where the text was edited and corrected based on the evidence from multiple sources. Subsequently the information was consolidated through summary tables and timelines that were constructed for 
each case, aggregating all data sources. NVivo software (version 10) ${ }^{1}$ was used to import all the raw data, and systematize the information across different sources, annotate it, and classify into nodes in preparation for data coding. The outputs of the coding were exported to an Excel coding book. Finally, the matching of theoretical concepts was implemented by mapping out patterns, dimensions, and their features against the proposed theoretical framework, which was simultaneously re-visited as a result of the data collection and analysis processes.

The data analysis was carried out simultaneously with the data collection, where initial categories were sought for within the established framework, then refined in light of the data, and connected back to the most suitable theoretical perspectives through multiple iterations. Following this procedure, the analysis was divided into two mutually informing processes. In one process, each case was considered individually with a focus on the entrepreneurial finance journey. In the second process and at the same time, cross-case analysis was implemented where, based on the first cases, initial categories were formed and subsequently built upon as new cases were exploited, re-visited in light of alternative avenues, or enriched with new evidence. The emerged categories were then aggregated into themes, which were then related to an appropriate theoretical perspective and informed a corresponding proposition. As a result, this approach provided an opportunity to capture the depth and richness of the data, while remaining focused on the pre-defined areas, and achieve research objectives (Al-Dajani et al. 2015).

In the following section, the 10 funding journeys are discussed individually, and the results of the cross-case analysis are aggregated into three themes.

\footnotetext{
${ }^{1}$ Nvivo is a software for qualitative data analysis. It was used for the purposes of data storage, data systematisation, annotation, and classification of the sources to assist the process of coding and subsequent analysis.
} 


\section{Limitations}

This study was designed to identify the interactional and dynamics prerequisites of both intentions and actual actions from the entrepreneur's perspective. While exposed to subjective biases, and pitfalls of recollections (Guercini 2014), the findings are of value because they capture common patterns across a sample of ten entrepreneurs in decision-making processes around a sensitive issue, which in some cases resulted in unsuccessful attempts, and undesired outcomes. This study included a period of recovery from a severe recession, and this may have affected the results. It is also confined to the Scottish urban context, which represents a specific cultural and economic setting, possibly restricting the generalisability and transferability of findings.

\section{Findings}

\section{Individual funding journeys}

Individual funding journeys were grouped depending on the finance route taken, and mapped against the time scale and the amount of money raised, where Year 1 was the starting point of the business (the first year that money was put in to the venture), which precedes or in certain cases coincided with the year of first sales.

The first group of entrepreneurs pursued equity capital to boost their growth and reach out to new markets (see Figure 2). Entrepreneur A started his business with a considerable amount of own savings, followed by small scale public grants, and a bank overdraft. After an unsuccessful attempt to pitch for business angels' investment to improve the chances to enter an international market, the founder had to refer to friends and family for financial help, struggling to make ends meet. Alternative finance temporarily boosted the business, however it could not withstand subsequent adverse macroeconomic circumstances. Similarly, Entrepreneur B launched his technological business with his own funds, but was also successful 
in securing private equity funding and investment from a family member (on equal terms with the other investors) to encourage the business growth, and establish manufacturing processes.

Entrepreneur F launched his capital-intensive venture with government grants and matching schemes to complement the individual investment from someone who was not a professional funder and tried to secure professional investment at a later stage. Entrepreneur $\mathrm{H}$ started with personal savings, followed by matching investments both from family and professional investors to fund expansion.

\section{[Insert}




\section{Figure 2 about here]}

The funding journeys of cases that followed the debt route are illustrated in Figure 3. Entrepreneur C started off with government grants and a bank credit, which were further complemented by a family loan on demand to finalize the design of the school. Entrepreneur D had a similar funding route; but did not manage to secure a bank loan, and turned to his family to preserve the ownership of the business. Both entrepreneurs C and D felt particularly protective over the control of their ventures, and keeping the business within family made more sense for them, rather than going to external investors. Entrepreneur G used public funds, bank finance, and a small family loan to fill in a short-term liquidity gap before her venture quickly became self-sustaining.

\section{[Insert Figure 3 about here]}

The remaining group is comprised of businesses, who either mixed equity and debt sources, or used alternative finance without explicitly pursuing a particular funding strategy (see Figure 4). Entrepreneur E relied on savings and public funding in the beginning, further topped up by a bank loan, and friends' equity injections to fill in the liquidity gaps. Family gift and a bank loan were the first and only options used by Entrepreneur I, pointing out that the receipt of family money pushed him towards launching his venture to make a good use of it. Finally, Entrepreneur $\mathrm{J}$ after failing to secure a bank loan, managed to raise the necessary funding on a reward-based crowdfunding platform, explicitly avoiding direct family support, and sharing ownership.

[Insert Figure 4 about here] 


\section{Theme 1: motivation behind entrepreneurial finance choice}

Each choice was carefully considered by entrepreneurs, who appeared to seek added value in their decisions. The categories of ownership protection, sharing expertise, and opportunities to expand professional networks run across all the cases, where professional funding was favoured over alternative sources due to its intangible benefits (see Table 3). Entrepreneur A sought private investments to strengthen the position of the venture and open up international markets from the very start of the business journey, till its maturity. Entrepreneur B expected high quality feedback from professional investors to set up the business. Entrepreneur $\mathrm{C}$ was looking for additional help to complement her purely educational background. While businesses A and B were manufacturers, and oriented towards growth (hence their choice of equity investors), business $\mathrm{C}$, the educational services provider, sought bank finance and government support along her mother's professional and financial help by leveraging on her knowledge and networks at the early stages of development, and expansion.

Ownership protection is revealed to be a substantive factor in decision making for entrepreneurs D, E, G, I, and J (all operated in services sector). As a result, none of them considered equity investments to preserve control as a sole owner (D and I), or as an original partnership (E, G, and J) to feed into start-up or commercialization stages, where businesses E, G, I and J are also characterized with lowest start-up costs in the sample. Notably, D, E and G still exhibited long-term growth intentions from the beginning, actually achieving those at the point of observation (see Table 2). Entrepreneur F was hoping to establish partnerships with both suppliers and retailers through the private investors' networks, whereas Entrepreneur H perceived reputational benefits from getting the business angels on board. Both ventures needed a substantial amount of funds to establish a manufacturing process (F), and to invest into the international expansion $(\mathrm{H})$. 


\section{[Insert Table 3 about here]}

These findings suggest that, when considering which sources of finance to approach, the entrepreneurs were driven by non-financial personal and business needs that could be fulfilled at a particular moment (e.g. professional knowledge, access to networks, building reputation, filling in the liquidity gaps), rather than their chances of securing the required sum of money from a particular source (such as venture type, stage of business development, the amount of capital required, own characteristics and financial input). This pattern is reflected in Analytical Theme 1 (Motivation behind entrepreneurial finance choice), worded in Proposition 1 as follows:

P1: Entrepreneurs are driven by the perceived value-added benefits that enable business development in line with their goals when considering sources of finance.

\section{Theme 2: the preferred versus actual sequence of finance sources}

Following from above, each entrepreneur reflecting on their own finance journey was able to outline their preferred choice of funding that was based on the business needs at a particular point in time. In all the cases, entrepreneurs relied on their own savings and public grants during the start-up stage to launch their venture, regardless of the size of the start-up capital and industry. However, depending on the size of the required capital, their own financial position, aspirations and business nature, multiple paths were considered. Businesses A, B, F, and H (notably, the first three are manufacturers with substantial start-up requirements, and $\mathrm{H}$ was a services business with high growth aspirations and working capital needs) reached out to private investors, either successfully from the first attempt (Cases B and H), second attempt Case (F), or unsuccessfully after two approaches (case A), as seen from Table 4. As such, their original intention, to obtain equity funding, was continually disrupted by the need to seek temporary and initially undesired/unconsidered solutions leveraging on their weak social ties from 
professional networks (see Table 2) to cover the gaps (cases A and F), or their need to match the equity funding to meet personal goals, or to reach the necessary limit utilizing close social connections (cases B and $\mathrm{H})$.

\section{[Insert Table 4 about here]}

In the remaining cases entrepreneurs sought to maintain their initial sole or shared ownership of the business, where banking products and subsequent re-investment into the business should have been able, in their view, to provide the required funding. In that way, entrepreneurs $\mathrm{C}, \mathrm{E}$, and $\mathrm{G}$ thought that the initial bank loan and secured public grant would be sufficient to kickstart the business that would eventually sustain itself. However, when facing an unexpected increase in demand for the service (cases C and G), and unpredictable liquidity issues (case E), they had to turn to close family members for financial support. Entrepreneurs D and J faced a dilemma when their bank application to enable business growth got rejected: either to step away from their original intention to keep the business ownership to themselves and start looking for private investments, or to find alternative ways to fund their ventures. As a result, D accepted family support (strong social ties), and $\mathrm{J}$ reached out to the crowd online (weak social ties). Finally, entrepreneur I, being able to cover his moderate start-up costs by means of initial input and bank loan, noted that he would never think of using family funds unless they were readily available as a gift.

While the preferred sequence of financial services gravitates towards the classic route of debt to equity balance, where control over the company is maintained initially and further external investments are sought in order to boost growth, the actual sequence tends to deviate from this desired scenario. In all the cases apart from $\mathrm{H}$, the journey starts with either personal savings or governments funds. Moreover, all entrepreneurs apart from B and I mentioned different forms of financial bootstrapping, where the resources they could access were used to save the 
use of cash, such as working from home, using personal vehicles, credit cards, and seeking help from personal networks (see Figures 2-4 for individual funding journeys). To support further business development, arms-length funding was sought, either private investments (cases A, B, F, and I), or bank loans (cases C, D, E, G, H, and J). The latter is also one of the earliest options entrepreneurs initially referred to $(\mathrm{C}, \mathrm{G}$, and $\mathrm{H})$, however, not in isolation, and complemented by public funds, own savings, and family support as a back-up in case the application was not successful. Therefore, there is a pattern in relation to the sequence of preferred funding sources, expressed as Proposition 2a:

P2a: Entrepreneurs first rely on own savings and bootstrapping, then attempt to secure funds from local public sources subject to their awareness of those, and afterwards consider bank finance when seeking to maintain control, and professional investors when looking for additional external opportunities.

The divergence between the preferred and actual finance paths becomes particularly evident when it comes to informal funding (from family, friends, and acquaintances). Contrary to the mainstream theoretical expectations, it was not initially considered by these entrepreneurs within their preferred finance path, but made use of when no other options were available, due to: unsuccessful experience with banks (cases D and J) or private investors (case A); the need to provide a matching source for complementary funding at a short notice (cases $\mathrm{F}$, and $\mathrm{H}$ ); to fill in liquidity gaps as they arise (cases C, E, G, and I); or meet personal obligations (case B). Even Entrepreneur I who used the family funds in the first instance, said: "I wouldn't take it, unless it was already there as my graduation gift from my aunt...”. Interestingly, some respondents demonstrated their reluctance to seek funding from family and friends, considering the ultimate use of these funds as something inevitable, imposed by some other factors, and, to some extent, unfortunate: "I never wanted to get to a stage where I was the one being proactive towards my family" (case A); "But my brother-in-law he wanted to invest, so I told the business 
angels that I didn't need as much from them" (case B); "This was the last remaining option" (case D); "So there were times, when he went in, so to find it elsewhere would have been tough" (case E); “At that stage it seemed as incredibly high risk...That's why we relied on a bit more the personal attachment" (case F); "There was no previous traction, there was no reputation we could trade on..." (case G); "I didn't have to borrow any money from a bank... Which obviously has advantages these days" (case I).

In cases where family and friend's involvement was less value-added (i.e. the funder did not provide any additional inputs apart from the financial one), entrepreneurs showed caution in mixing personal and business relationships: "You have to be careful about involving family members in the business" (case B); "I did not want to single out my parents" contribution, and for them to feel that we took advantage in some way..." (case J). Some respondents managed both social and business aspects successfully: "I didn't go to anywhere else, because my mom had already the shortfall, so it was easy" (case C); "We've done a very good job, we're keeping our personal relationship away from our business" (case E); "So it's as much a personal relationship as it is a business relationship" (case F). Cases H and D emphasized the circularity of financial flows within family: "I suppose, they [parents] view all as their own money" (case H); "Because why they're doing this, everything they have when they die, if there's anything left, will come to us anyway" (case D). However, entrepreneurs acknowledged the implicit dangers of involving social relationships in the business decisions, for example if the business outcome were to be unsuccessful: “...then it, probably, would have killed their friendship" (case A), or if external board members were involved on par with the family members: "So the dynamics of the business has changed...Because it was a personal connection there, it was difficult" (case G). 
Therefore, there is an indication of the divergence between preferred and the actual finance path, caused by funding gaps and contingencies arising that were resolved by informal funding, as expressed in Proposition 2b:

P2b: Entrepreneurs resort to family and friends finance when first choice options are not available, and when under pressure to achieve business and personal goals.

\section{Theme 3: the dynamism of finance escalator}

When analysing the roots of the divergence between the preferred and actual finance paths, the force of circumstances, and the need for fast decisions, shapes the actual choices of entrepreneurs, which might deviate from their initially desired options. This dynamism suggests the non-linearity of the trajectory of the finance choices: either in terms of the sequence of the sources and the amounts of money sought; or in terms of the 'change of course' depending on the specific situational context. The presence of an urgent need encourages entrepreneurs to take the first available option, even if it is the least preferable or has not been considered before. Such an urgency emerges from temporary short-term cash gaps to maintain the operations or reach out to further funding (cases E, H, G), from a certain level of despair when other sources either are not available, or perceived to be not accessible (cases C, J, F), a lack of preparation, which is never acknowledged, but rationalized or explained away by reference to external circumstances (cases A, D, and I), or personal arrangements and obligations (case B). Hence, situational settings affect the funding choice in a time-constrained environment, making each individual finance journey dynamic by responding to urgent needs and contextual environment, rather than following an earlier pre-determined plan (if such exists).

All entrepreneurs demonstrated their response to the surrounding context when making finance (and more generally, business) decisions. Almost all who started their business before or right after 2009, referred to recession as a factor constraining the use of most preferable financial 
options (cases A, D, E, F, G, and H). Regardless of whether they attempted unsuccessfully to attract formal funding (cases A, F), or were discouraged from going to banks or investors (cases D, E and F), they referred to the macroeconomic climate as a reason for such an outcome. In several cases, local context determined the use of certain funding sources. These included the proximity to the necessary infrastructure (case C); favourable positioning of being part of the University Business Incubator (case B); local networking opportunities (case J); and finally a convenient location (case I). Moreover, apart from external factors such internal parameters as unpreparedness, lack of skills and expertise (cases A, C, and F), or the need for further business development (case B) pushed entrepreneurs into exploring additional funding opportunities.

\section{[Insert Table 5 about here]}

Notably, entrepreneurs who demonstrated the most dynamic finance choices (in terms of the 'changes of courses' in their financial decisions) - A, E, D, F (as seen from Table 5), and the lack of planning (entrepreneur C) were located in the most deprived local areas, although representing various sectors, and situations when their needs occurred. Moreover, all the cases who referred to informal funds have maintained their social relationships even if the business side failed (A), or did not perform up to the expected level (C, F). Where personal and business side came into tension, they were subsequently diverged either by exiting the personal relationship (case E): “And then there was also my...then partner; best friend and a business partner now...", or business relationship (case G): "But at that time it was two against one vote, so... I had to go with the majority. It was quite difficult, quite a painful process, because he found he had given so much to be seen off the way he was, it wasn't a particularly pleasant process for anybody to go through, to be honest", demonstrating the importance of demarcation between personal and business sides. In the situation, where direct family support was avoided (case J), an alternative way was arranged to leverage on informal funds (crowdfunding). These 
patterns suggest that the availability of opportunities to fill in the gaps and to be dynamic is further explained by the particular context in the social setting, local surrounding, and macroeconomic environment.

P3: The finance escalator represents a set of dynamic decisions as a response to situational factors in terms of availability and accessibility of finance sources at the social, local, and macroeconomic levels.

\section{Discussion}

In this paper, the type and sequence of sources of funding used by businesses at different stages of business development is considered in order to understand the trajectory and reasoning behind these decisions, taking into account the embeddedness of an entrepreneur in a particular context. The traditional finance escalator representation, which relies on pecking order and trade-off theories to explain the sequence of financial choices at a firm level (Martinez, Scherger, and Guercio 2019), only partially supports the findings. Accordingly, in this section, a new framework is proposed that captures divergence, dynamism, and situational contextdependence of entrepreneurial finance paths.

In line with the previous studies, it appears that stage of development, industry (including the start-up capital requirements), entrepreneurial growth orientations, the purpose of funding (Block et al. 2018; Mason and Harrison 2001; Greene, Brush, and Brown 2015), and the level of risk associated with the business activities (Hechavarría, Matthews, and Reynolds 2016) imposed variations in the choice of finance sources among the entrepreneurs in this study. Finance journeys typical started with own savings, supported by bootstrapping techniques and public grants for any type of venture. Further on, businesses oriented for growth with high capital expenditures (not only limited to manufacturing sectors) opted for an equity route, seeking for value-added benefits, such as shared expertise and access to networks. Services 
sector cases, characterised by low start-up costs, regardless of growth orientation tended to preserve business ownership in the hands of the original founder(s), or within a close and trusted circle of people. As a result, they pursued debt finance, and started involving family members, friends, or non-equity funding from third parties (e.g. crowdfunding) only to keep the venture going and fill in liquidity gaps.

In this way, Theme 1 emerges, where the argument stands as follows: when considering sources of finance entrepreneurs are driven by their anticipated business and personal needs, rather than their chances (or readiness) of securing a particular funding source. This pattern links to the embeddedness concept, where they attempt to extract value from what is available around them: existing resources, professional networks, and emerging opportunities to maximise the benefit for their venture. Contrary to the prevailing view in the entrepreneurial finance literature (e.g. Greene, Brush, and Brown 2015; Cassar 2004), the financial decisions of entrepreneurs are driven not by the consideration of availability and accessibility of financial sources based on a range of objective parameters, but by the current personal or business need in terms of the value sought, and the situational context at a particular moment in time (Proposition 1). As such, consideration of and access to resources is determined by entrepreneurs' social surrounding through their involvement in networks, which entrepreneurs actively seek to expand to gain added value in line with the social embeddedness and bridging perspectives (McKeever, Jack, and Anderson 2015; Korsgaard, Ferguson, and Gaddefors 2015). It is also confined to the local opportunities, convenience, and perceptions of external environment. Moreover, all these factors interplay with each other depending on a particular situation (Anderson, Drakopoulou Dodd, and Jack 2012).

However, entrepreneurs are faced with the challenge to make fast, unplanned decisions in order not to run out of cash, where their preferred paths start diverging due to unforeseen circumstances (Theme 2). In such situations the role of social embeddedness is particularly 
acute, although twofold. From one side, entrepreneurs tend to reach to close social ties (family, friends, and colleagues) or more distant social surrounding (crowdfunding) to make use of opportunities there to fund their ventures fast and without compromising other goals (e.g. sharing ownership with external investors, or spending time and money on sorting out alternative funding sources). From the other side, they indicate reluctance to do so in case of damage or strain to the social relationship, or negative impact on business development through the mixed signals to non-affiliated stakeholders as suggested by several studies (Klyver et al. 2016; Lee and Persson 2016; Robb and Robinson 2012). As such, the value of bridging across various social contexts is appreciated, although not always implemented due to time constraints, and conflicting interests.

In summary, where an entrepreneur's preference is to seek equity investment to boost business growth and potential, arising hurdles prompt them to turn to alternative options, such as debt or friends and family support, as a conscious, available choice used as a stepping stone to reach the ultimate goal. In a similar way, where a debt route of finance is preferred, deviations can occur when certain trade-offs are imposed by circumstance, such as failure to secure the desired funding source, unpredicted/unplanned funding shortages, or reluctance to share ownership with strangers.

The preferred choice largely depends on the stage of the business development, entrepreneurial growth aspirations and the selected funding route: either equity or debt. While starting with own savings, bootstrapping, and resorting to public grants, entrepreneurs will either aim to secure bank loans, or reach out to professional investors (Proposition 2a). Notably, bank funding (both business products and personal credits as a form of bootstrapping) is considered when entrepreneurs' first priority is to maintain control over their venture. As a result, in line with recent evidence, banks are among the most favoured sources of finance (Hart et al. 2018). 
At the same time, equity funding is sought for to fund more capital-intensive ventures oriented to growth. Therefore, unlike traditional representations of the finance escalator, informal funds are more likely to be preceded by public grants, bank applications, and professional private investments (including both successful and unsuccessful attempts), where additional nonpecuniary benefits are pursued by entrepreneurs depending on the selected route: equity or debt finance path (Proposition 2b).

The divergence of the preferred path from the actual one is prompted by both internal and external factors, where the former are referred to on reflection (the level of unpreparedness, the lack of experience and knowledge, or the risk of the venture), and the latter drive decisions in the moment of need. Their references to the local infrastructure, local networking opportunities, and convenience indicate the presence of spatial embeddedness that entrepreneurs capitalize on, and tend not to reach beyond. The impact of the macroeconomic environment forms attitudes towards their chances of securing bank or equity finance; their cultural setting feeds the need for independence (ownership protection) and their estimate of their own abilities and their ventures' potential when considering informal funding. Entrepreneurs tackle gaps in funding availability, when fast and agile solutions are needed, by looking for alternative readily available mechanisms, such as bootstrapping at the initial stage of business development and informal funding and crowdfunding at further commercialization and growth stages. This evidences the presence of institutional embeddedness and continuous interplay across social, spatial, and institutional layers, resulting in a dynamic representation of the finance escalator as opposed to its traditional static version, which is captured in Theme 3.

Ultimately, individual factors, such as discouragement from borrowing, and negative expectations (Kon and Storey 2003), the level of preparedness or investment readiness (Mason and Harrison 2004; Irwin, Pattinson, and Scott 2014; Fellnhofer 2015), as well as the perception of external environment (Bacq et al. 2017) define the availability of desired finance 
options to entrepreneurs, and shape their actual choices of funding. These actual choices are rooted in social, local, and institutional contexts, and address failures and gaps faced throughout the journey at each of its stages, indicating the dynamism of the finance escalator in terms of its divergence from intended paths, and non-linearity of financial decisions arising from their short term exigencies (the nightmare of insufficient cash to run the business) (Proposition 3).

In light of these findings, a re-visited finance escalator is presented in Figure 5, which is characterized by a dynamic nature, depending on the selected finance route (equity or debt). While own savings and bootstrapping provide a starting point for financing a new venture, depending on their preferences and firm characteristics entrepreneurs seek to approach either formal lending institutions or professional investors (either successfully, or unsuccessfully). In the model, the outcome at this step will determine the use of informal funding (family, friends, or other individuals who are not professional investors). Banks appear to be the most obvious option after financial bootstrapping, unless an entrepreneur is intentionally looking either for more growth-inducing options, or professional advice. Where bank funding is less attractive or accessible, alternative finance (e.g. crowdfunding) when the business model allows for it, or government support are sought for. As such, the final shape of a finance escalator is proposed to be contingent on a combination of such factors as: individual priorities, aspirations, and needs, the level of the social, spatial, and institutional embeddedness that gives access to knowledge, information about available finance options, and subsequently - access to them, and the ability to reach out to new networks, locations, and mechanisms to address the business needs, and fill in the gaps in a prompt manner.

\section{[Insert Figure 5 about here]}

\section{Conclusion}

The novelty of this study arises from its focus on the divergence between preferred and actual 
entrepreneurial finance paths, and the consequent dynamic nature of the finance escalator, given its susceptibility to the impact of contextual factors across three layers: social, spatial, and institutional. The study contributes to the entrepreneurship literature in two ways. First, it complements the literature on entrepreneurial finance, and, in particular the demand for and use of financial sources throughout the business development process, and funding gaps. There is prior evidence that entrepreneurs originally pursue different finance paths, depending on their capital needs and growth aspirations (Greene, Brush, and Brown 2015; Owen, Deakins, and Savic 2019). However, our findings reveal that they take into consideration personal and business needs when making their decisions on which sources to pursue, regardless of any other parameters, as far as their preferred route is concerned. This research further explains the origin and nature of funding gaps, and how they are filled in, resulting in a divergence from the preferred finance trajectory.

Second, the study contributes to the multi-layered embeddedness literature, where the level of integration with the context defines the actual use of financial resources across three layers: social, spatial, and institutional. The findings emphasize the value of social ties in obtaining financial capital, as well as their use, which is contingent on geographical proximity and convenience. Moreover, under unfavourable conditions (at individual, local, or macroeconomics levels), utilizing close social ties is regarded as a second choice to fill in the gaps, give a boost, or even to rescue a business venture. The results, therefore, reinforce the positive impact of social embeddedness on firms' access to resources in situations when access to alternative sources is restrained. As such, a thoughtful utilisation of personal networks is particularly relevant for disadvantaged entrepreneurs (Wang and Altinay 2012).

Spatial embeddedness of entrepreneurs is manifested through their local attempts to secure funding, especially when the necessity arises to close funding gaps. It is closely related to the availability of social ties and connections that enable entrepreneurs to reach out to 
alternative funding sources, and being more agile in response to urgent need. This highlights the importance of the local infrastructure, and managing gaps at the local level, so that financial flows are directed to the right recipients to maximise the value of entrepreneurial action. The implementation of such a policy may require local support to shape regional entrepreneurial activity (Gertler 2010) and policy customization, which takes local context and needs into account (Mason and Brown 2013).

The use of both social and spatial embeddedness is contingent on the institutional context, and how entrepreneurs perceive its constraints and opportunities, and translate them into financial decisions. The use of informal funds as a second choice, a notable feature of the sample, may be rooted in the cultural setting, where mixing of personal and business lives is avoided, and the need for independence is dominant when launching a business. In other settings where family businesses may be more prevalent, and the banking system less mature, patterns may differ. Moreover, the state of the finance market, and its perception based on the ongoing macroeconomic developments drove decision-making of the entrepreneurs in this sample towards justifying their reliance on if not preference for social networks as sources of finance.

While this study provides some surprising findings - that funding from family and friends is "second choice" funding, not "first port of call" funding - in a wider sense it reaffirms the multi-layered embeddedness of all entrepreneurial behaviour (Welter, 2010). While the ten entrepreneurs in this study knew that professional finance was superior to cash from family and friends, circumstances compelled most of them to opt for informal investment and come up with an ex post facto justification for doing so. Ironically, while autonomy is the primary motivation for starting a business, this study shows that entrepreneurs are, in many ways, prisoners of their context. 
Future longitudinal studies would allow the investigation of the dynamics of the finance escalator over a longer time frame to identify constant and variable factors affecting the demand for entrepreneurial finance. Replication in other contexts, where different trust and obligation dynamics in family and non-family relationships apply, could reveal different patterns. Further insights into the geographical allocation of resources would give an understanding of the finance escalator across areas that vary in prevalence of entrepreneurial activity, and the supply of entrepreneurial finance. Alternative sources of funding, rapidly proliferating, and taking the forms of crowdfunding, peer-to-peer lending, other forms of online secondary markets, and microfinance raise options for a new wave of research, in which their mechanisms and impacts are explored, and linked to business growth (Zhang et al. 2018). A comparative analysis across industries to identify peculiarities of, for example, technology-based versus retail or servicebased businesses could supply more fine-grained implications for policy-makers and practitioners.

\section{Declaration of interest statement}

On behalf of both authors, the corresponding author states that there is no conflict of interest. 


\section{References}

Al-Dajani, H., S. Carter, E. Shaw, and S. Marlow. 2015. "Entrepreneurship among the displaced and dispossessed: Exploring the limits of emancipatory entrepreneuring." British Journal of Management 26 (4):713-30.

Anderson, A. R., S. Drakopoulou Dodd, and S. L. Jack. 2012. "Entrepreneurship as connecting: some implications for theorising and practice." Management Decision.

Anderson, Alistair, and Sébastien Ronteau. 2017. "Towards an entrepreneurial theory of practice; emerging ideas for emerging economies." Journal of Entrepreneurship in Emerging Economies.

Audretsch, David B, Erik E Lehmann, Stefano Paleari, and Silvio Vismara. 2016. "Entrepreneurial finance and technology transfer." The Journal of Technology Transfer 41 (1):1-9.

Bacq, Sophie, Laurel F Ofstein, Jill R Kickul, and Lisa K Gundry. 2017. "Perceived entrepreneurial munificence and entrepreneurial intentions: A social cognitive perspective." International Small Business Journal 35 (5):639-59.

Baldock, Robert, and Colin Mason. 2015. "Establishing a new UK finance escalator for innovative SMEs: the roles of the Enterprise Capital Funds and Angel Co-Investment Fund." Venture Capital 17 (2):1-28.

Barclays. 2017. "Venture capital in the UK."

Berger, Allen, and Gregory Udell. 1998. "The economics of small business finance: The roles of private equity and debt markets in the financial growth cycle." Journal of Banking \& Finance 22 (6):613-73.

Bird, Miriam, and Thomas Zellweger. 2018. "Relational embeddedness and firm growth: Comparing spousal and sibling entrepreneurs." Organization science 29 (2):264-83.

Block, Joern H, Massimo G Colombo, Douglas J Cumming, and Silvio Vismara. 2018. "New players in entrepreneurial finance and why they are there." Small Business Economics 50 (2):239-50.

Boettke, P.J., and C.J. Coyne. 2009. Context matters: Institutions and entrepreneurship. 3 vols. Vol. 5, Foundations and Trends in Entrepreneurship. Hanover, MA: Now Publishers Inc.

Brinkmann, Svend. 2014. Interview. New York: Springer. 
Bruton, Garry, Susanna Khavul, Donald Siegel, and Mike Wright. 2015. "New Financial Alternatives in Seeding Entrepreneurship: Microfinance, Crowdfunding, and Peer-toPeer Innovations." Entrepreneurship Theory and Practice 39 (1):9-26.

Burt, R.S. 1997. "The contingent value of social capital." Administrative Science Quarterly $42(2): 339-65$.

— 2000. "The network entrepreneur." In Entrepreneurship: the social science view, edited by Richard Swedberg, 281-307. Oxford: Oxford University Press.

_. 2004. "Structural holes and good ideas." American Journal of Sociology 110 (2):349-99.

Cassar, G. 2004. "The financing of business start-ups." Journal of Business Venturing 19 (2):261-83.

Chemmanur, Thomas J, and Paolo Fulghieri. 2014. "Entrepreneurial finance and innovation: An introduction and agenda for future research." Review of financial studies 27 (1):119.

Cleaver, Frances. 2001. "Institutional bricolage, conflict and cooperation in Usangu, Tanzania." IDS bulletin 32 (4):26-35.

Collis, J., and R. Hussey. 2014. Business Research: a practical guide for undergraduate and postgraduate students. 4 ed. London: Palgrave.

Companies Act. 2006. Parliament of the United Kingdom.

Corbin, Juliet, and Anselm Strauss. 2008. Basics of qualitative research: techniques and procedures for developing grounded theory. 3rd edition ed. Thousand Oaks: Sage Publications, Inc.

Cowling, Marc, Marc Cowling, Weixi Liu, Weixi Liu, Ning Zhang, and Ning Zhang. 2016.

"Access to bank finance for UK SMEs in the wake of the recent financial crisis." International Journal of Entrepreneurial Behavior \& Research 22 (6):903-32.

Cresswell, Tim. 2006. Place: a short introduction Malden, MA: Blackwell.

Creswell, John W. 2013. Research design: Qualitative, quantitative, and mixed methods approaches. 4 ed. Thousand Oaks: Sage publications.

Cumming, Douglas J, and Silvio Vismara. 2017. "De-segmenting research in entrepreneurial finance." Venture Capital 19 (1-2):17-27.

Dacin, M Tina, Jerry Goodstein, and W Richard Scott. 2002. "Institutional theory and institutional change: Introduction to the special research forum." Academy of Management Journal 45 (1):45-56. 
Dacin, M Tina, Marc J Ventresca, and Brent D Beal. 1999. "The embeddedness of organizations: Dialogue \& directions." Journal of Management 25 (3):317-56.

De Carolis, Donna Marie, and Patrick Saparito. 2006. "Social capital, cognition, and entrepreneurial opportunities: A theoretical framework." Entrepreneurship Theory and Practice 30 (1):41-56.

Desa, Geoffrey. 2012. "Resource mobilization in international social entrepreneurship: Bricolage as a mechanism of institutional transformation." Entrepreneurship Theory and Practice 36 (4):727-51.

Dubois, Anna, and Lars-Erik Gadde. 2002. "Systematic combining: an abductive approach to case research." Journal of Business Research 55 (7):553-60.

Eisenhardt, Kathleen M., and Melissa E. Graebner. 2007. "Theory building from cases: opportunities and challenges." Academy of Management Journal 50 (1):25-32.

Fellnhofer, Katharina. 2015. "Literature review: investment readiness level of small and medium sized companies." International Journal of Managerial and Financial Accounting 7 (3/4):268-84.

Gaddefors, Johan, and Alistair R Anderson. 2019. "Romancing the rural: Reconceptualizing rural entrepreneurship as engagement with context (s)." The International Journal of Entrepreneurship and Innovation 20 (3):159-69.

Gertler, Meric S. 2010. "Rules of the game: the place of institutions in regional economic change." Regional studies 44 (1):1-15.

Glaser, B. G., and A. L. Strauss. 1967. The discovery of grounded theory: Strategies for qualitative research. Chicago: Aldine.

Greene, Patricia G, Candida G Brush, and Terrence E Brown. 2015. "Resources in small firms: an exploratory study." Journal of Small Business Strategy 8 (2):25-40.

Griffin, Mark A. 2007. "Specifying organizational contexts: Systematic links between contexts and processes in organizational behavior." Journal of Organizational Behavior:859-63.

Guercini, Simone. 2014. "New qualitative research methodologies in management." Management Decision 52 (4):662-74.

Gulati, Ranjay. 1995. "Does familiarity breed trust? The implications of repeated ties for contractual choice in alliances." Academy of Management Journal 38 (1):85-112.

Hanssens, Jürgen, Marc Deloof, and Tom Vanacker. 2016. "The evolution of debt policies: New evidence from business startups." Journal of Banking \& Finance 65:120-33. 
Harrison, Richard. 2013. "Crowdfunding and the revitalisation of the early stage risk capital market: catalyst or chimera?" Venture Capital 15 (4):283-7.

Hart, M., K. Bonner, and J. Levie. 2016. "Global Entrepreneurship Monitor United Kingdom 2016 Monitoring Report." In.

Hart, Mark, Karen Bonner, Laura Heery, Neha Prashar, and Jonathan levie. 2018. "Global Entrepreneurship Monitor: United Kingdom 2018 Monitoring Report." In.

Hechavarría, Diana M, Charles H Matthews, and Paul D Reynolds. 2016. "Does start-up financing influence start-up speed? Evidence from the panel study of entrepreneurial dynamics." Small Business Economics 46 (1):137-67.

Hite, Julie M., and William S. Hesterly. 2001. "The evolution of firm networks: From emergence to early growth of the firm." Strategic Management Journal 22 (3):27586.

Irwin, David, Steve Pattinson, and Jonathan M Scott. 2014. "Local Enterprise Agency loan funds and investment readiness in UK small firms." Local Economy 29 (1-2):9-21.

Jack, Sarah L, and Alistair R Anderson. 2002. "The effects of embeddedness on the entrepreneurial process." Journal of Business Venturing 17 (5):467-87.

Jeffrey, Scott A, Moren Lévesque, and Andrew L Maxwell. 2016. "The non-compensatory relationship between risk and return in business angel investment decision making." Venture Capital:1-21.

Kenessey, Zoltan. 1987. "The primary, secondary, tertiary and quaternary sectors of the economy." Review of Income and Wealth 33 (4):359-85.

Klyver, Kim, and Kevin Hindle. 2007. "The role of social networks at different stages of business formation." Small Enterprise Research 15 (1):22-38.

Klyver, Kim, Noel J Lindsay, K Suleiman, and Gary Hancock. 2016. "Altruistic investment decision behavior in early-stage ventures." Small Business Economics:1-18.

Kon, Yoshinori, and David J Storey. 2003. "A theory of discouraged borrowers." Small Business Economics 21 (1):37-49.

Korsgaard, Steffen, Richard Ferguson, and Johan Gaddefors. 2015. "The best of both worlds: how rural entrepreneurs use placial embeddedness and strategic networks to create opportunities." Entrepreneurship \& Regional Development 27 (9-10):574-98.

Kotha, Reddi, and Gerard George. 2012. "Friends, family, or fools: Entrepreneur experience and its implications for equity distribution and resource mobilization." Journal of Business Venturing 27 (5):525-43. 
Larson, Andrea, and Jennifer A. Starr. 1993. "A network model of organization formation." Entrepreneurship Theory and Practice 17 (2):5-16.

Lee, Samuel, and Petra Persson. 2016. "Financing from family and friends." Review of financial studies 29 (9):1-65.

Leech, Nancy L, and Anthony J Onwuegbuzie. 2007. "An array of qualitative data analysis tools: A call for data analysis triangulation." School psychology quarterly 22 (4):55784.

Levie, J., and E. Autio. 2011. "Regulatory burden, rule of law, and entry of strategic entrepreneurs: an international panel study." Journal of Management Studies.

Mäkelä, M.M., and R.V. Turcan. 2007. "Building grounded theory in entrepreneurship research." In Handbook of Qualitative Research Methods in Entrepreneurship, edited by H. Neergaard and J.P. Ulhøi, 122-43. Cheltenham: Edward Elgar.

Marsden, Peter V, and Jeanne S Hurlbert. 1988. "Social resources and mobility outcomes: A replication and extension." Social forces 66 (4):1038-59.

Marshall, J. Neill. 2004. "Financial institutions in disadvantaged areas: a comparative analysis of policies encouraging financial inclusion in Britain and the United States." Environment and Planning A 36 (2):241-62.

Martinelli, Alberto. 2004. "The social and institutional context of entrepreneurship." Crossroads of entrepreneurship 3:53-73.

Martinez, Lisana B, Valeria Scherger, and M Belén Guercio. 2019. "SMEs capital structure: trade-off or pecking order theory: a systematic review." Journal of Small Business and Enterprise Development 26 (1):105-32.

Mason, Colin. 2017. "Financing Entrepreneurial Ventures." In The SAGE Handbook of Small Business and Entrepreneurship, edited by Robert Blackburn, Dirk De Clercq and Jarna Heinonen, 321-49. London: SAGE Publications Ltd.

Mason, Colin, Tiago Botelho, and Richard Harrison. 2016. "The transformation of the business angel market: empirical evidence and research implications." Venture Capital 18 (4):321-44.

Mason, Colin, and Ross Brown. 2013. "Creating good public policy to support high-growth firms." Small Business Economics 40 (2):211-25.

Mason, Colin M, and Richard T Harrison. 2001. "'Investment readiness': A critique of government proposals to increase the demand for venture capital." Regional studies 35 (7):663-8. 
_. 2004. "Improving access to early stage venture capital in regional economies: a new approach to investment readiness." Local Economy 19 (2):159-73.

Mason, Colin, and Yannis Pierrakis. 2013. "Venture capital, the regions and public policy: the United Kingdom since the post-2000 technology crash." Regional studies 47 (7):1156-71.

McKeever, Edward, Sarah Jack, and Alistair Anderson. 2015. "Embedded entrepreneurship in the creative re-construction of place." Journal of Business Venturing 30 (1):50-65.

Meek, William R, Desirée F Pacheco, and Jeffrey G York. 2010. "The impact of social norms on entrepreneurial action: Evidence from the environmental entrepreneurship context." Journal of Business Venturing 25 (5):493-509.

Miles, Matthew B, and A Michael Huberman. 1994. Qualitative data analysis: An expanded sourcebook. 2nd Edition ed. Thousand Oaks, CA: Sage.

Müller, Sabine, and Steffen Korsgaard. 2018. "Resources and bridging: the role of spatial context in rural entrepreneurship." Entrepreneurship \& Regional Development 30 (12):224-55.

Myers, S.C. 1984. "Capital structure puzzle." In.: National Bureau of Economic Research Cambridge, Mass., USA.

North, D.C. 1990. Institutions, institutional change and economic performance. Cambridge, UK: Cambridge University Press.

North, David, Robert Baldock, and Farid Ullah. 2013. "Funding the growth of UK technology-based small firms since the financial crash: are there breakages in the finance escalator?" Venture Capital 15 (3):237-60.

Owen, Robyn, David Deakins, and Maja Savic. 2019. "Finance pathways for young innovative small-and medium-size enterprises: A demand-side examination of finance gaps and policy implications for the post-global financial crisis finance escalator." Strategic Change 28 (1):19-36.

Pierrakis, Yannis, and George Saridakis. 2017. "Do publicly backed venture capital investments promote innovation? Differences between privately and publicly backed funds in the UK venture capital market." Journal of Business Venturing Insights 7:5564.

Reitan, B., and R. Sørheim. 2000. "The informal venture capital market in Norway? investor characteristics, behaviour and investment preferences." Venture Capital: An international journal of entrepreneurial finance 2 (2):129-41. 
Robb, Alicia M, and David T Robinson. 2012. "The capital structure decisions of new firms." Review of financial studies 27 (1):153-74.

Shane, S. 2003. A general theory of entrepreneurship: the individual-opportunity nexus. Cheltenham, UK: Edward Elgar.

Small Business Survey. 2017. Department for Business, Energy \& Industrial Strategy.

Strauss, Anselm, and Juliet Corbin. 1990. Basics of qualitative research: grounded theory, procedures and techniques. Newbury Park: Sage Publications, Inc.

Tang, Huan. 2019. "Peer-to-peer lenders versus banks: substitutes or complements?" The Review of Financial Studies 32 (5):1900-38.

Uzzi, Brian. 1997. "Social structure and competition in interfirm networks: The paradox of embeddedness." Administrative Science Quarterly 42 (1):35-67. . 1999. "Embeddedness in the making of financial capital: How social relations and networks benefit firms seeking financing." American sociological review 64 (4):481505.

Van Osnabrugge, M. 2000. "A comparison of business angel and venture capitalist investment procedures: an agency theory-based analysis." Venture Capital: An international journal of entrepreneurial finance 2 (2):91-109.

Wang, Catherine L, and Levent Altinay. 2012. "Social embeddedness, entrepreneurial orientation and firm growth in ethnic minority small businesses in the UK." International Small Business Journal 30 (1):3-23.

Welter, Friederike. 2011. "Contextualizing entrepreneurship — conceptual challenges and ways forward." Entrepreneurship Theory and Practice 35 (1):165-84.

Welter, Friederike, and David Smallbone. 2011. "Institutional perspectives on entrepreneurial behavior in challenging environments." Journal of Small Business Management 49 (1):107-25.

White, Brett A, and John Dumay. 2017. "Business angels: a research review and new agenda." Venture Capital 19 (3):183-216.

Wigren-Kristofersen, Caroline, Steffen Korsgaard, Ethel Brundin, Karin Hellerstedt, Gry Agnete Alsos, and Jorunn Grande. 2019. "Entrepreneurship and embeddedness: dynamic, processual and multi-layered perspectives." In.: Taylor \& Francis.

Winborg, Joakim. 2015. "The role of financial bootstrapping in handling the liability of newness in incubator businesses." The International Journal of Entrepreneurship and Innovation 16 (3):197-206. 
Winborg, Joakim, and Hans Landström. 2001. "Financial bootstrapping in small businesses: examining small business managers' resource acquisition behaviors." Journal of Business Venturing 16 (3):235-54.

Yang, Keming. 2004. "Institutional holes and entrepreneurship in China." The Sociological Review 52 (3):371-89.

Yin, Robert K. 2009. Case study research: design and methods. 4 ed, Applied social research methods series. Thousand Oaks: Sage Publications, Inc.

Zhang, Bryan, Tania Ziegler, Leyla Mammadova, Daniel Johanson, Mia Gray, and Nikos Yerolemou. 2018. "The 5th UK Alternative Finance Industry Report." 
Table 1 Interview guide structure

\begin{tabular}{|ll|}
\hline $\begin{array}{l}\text { Reference to the theoretical concepts } \\
\text { Business development, risk, and } \\
\text { individual characteristics }\end{array}$ & $\begin{array}{l}\text { Interview Guide Section (main themes) } \\
\text { Reflection on business and entrepreneurial skills } \\
\text { development }\end{array}$ \\
\hline $\begin{array}{l}\text { Individual finance escalator } \\
\text { representation }\end{array}$ & $\begin{array}{l}\text { Funding sources approached (timing, sequence, } \\
\text { amount, purpose, outcomes and conditions) }\end{array}$ \\
\hline & The nature of the funding decision \\
\hline Decision-making process & $\begin{array}{l}\text { - motivation and reasoning } \\
\text { - alternative considerations }\end{array}$ \\
\hline & $\begin{array}{l}\text { - anticipated outcomes } \\
\text { - post funding reflection }\end{array}$ \\
\hline $\begin{array}{l}\text { Contextual embeddedness versus } \\
\text { individual and/or business parameters }\end{array}$ & $\begin{array}{l}\text { - personal attributes, experiences, skills, and } \\
\text { circumstances }\end{array}$ \\
\hline Social embeddedness & - the role of family, friends, and colleagues \\
\hline Spatial embeddedness & $\begin{array}{l}\text { - available infrastructure and local } \\
\text { opportunities }\end{array}$ \\
\hline Institutional embeddedness & $\begin{array}{l}\text { - the impact of other (anticipated and } \\
\text { unexpected) external factors }\end{array}$ \\
\hline
\end{tabular}


Table 2 Description of the cases

\begin{tabular}{|c|c|c|c|c|c|c|c|}
\hline & $\begin{array}{l}\text { Informal } \\
\text { funding } \\
\text { received }\end{array}$ & Finance route & $\begin{array}{l}\text { SIMD } \\
\text { Decile }\end{array}$ & $\begin{array}{l}\text { Year of } \\
\text { First Sales }\end{array}$ & Sector & $\begin{array}{l}\text { Start-up } \\
\text { capital range, } \\
\text { thousand } \\
\text { pounds }\end{array}$ & $\begin{array}{l}\text { Business } \\
\text { Performance } \\
\text { (for the } \\
\text { observation } \\
\text { year) }\end{array}$ \\
\hline A & $\begin{array}{l}\text { Friend (equity, } \\
<10 \% \text { ) }\end{array}$ & Equity & 9 & 2006 & Retail (food services) & $300-350$ & Failed \\
\hline B & $\begin{array}{l}\text { Family (equity, } \\
<10 \% \text { ) }\end{array}$ & Equity & 7 & 2011 & $\begin{array}{l}\text { Manufacturing } \\
\text { (electric products) }\end{array}$ & $250-300$ & Loss \\
\hline $\mathrm{C}$ & Family (loan) & Debt & 10 & 2006 & $\begin{array}{l}\text { Pre-primary/primary } \\
\text { education }\end{array}$ & $45-50$ & Loss \\
\hline $\mathrm{D}$ & Family (loan) & Debt & 8 & 2010 & Care services & $50-55$ & Profit \\
\hline $\mathrm{E}$ & $\begin{array}{l}\text { Ex-partner } \\
\text { (equity, } 40 \% \text { ) }\end{array}$ & Mixed & 10 & 2006 & $\begin{array}{l}\text { International } \\
\text { employment } \\
\text { placement agency }\end{array}$ & $30-35$ & Profit \\
\hline $\mathrm{F}$ & $\begin{array}{l}\text { Friend (equity, } \\
<10 \% \text { ) }\end{array}$ & Equity & 10 & 2006 & $\begin{array}{l}\text { Manufacturing } \\
\text { (children toys) }\end{array}$ & $800-850$ & Loss \\
\hline $\mathrm{G}$ & Family (loan) & Debt & 10 & 2000 & $\begin{array}{l}\text { Employment } \\
\text { placement agency }\end{array}$ & $30-35$ & Profit \\
\hline $\mathrm{H}$ & $\begin{array}{l}\text { Family (equity, } \\
<10 \% \text { ) }\end{array}$ & Equity & 10 & 2003 & $\begin{array}{l}\text { Hotels and similar } \\
\text { accommodation }\end{array}$ & $>1000$ & Profit \\
\hline I & Family (gift) & $\begin{array}{l}\text { Alternative } \\
\text { finance/debt }\end{array}$ & 1 & 2013 & $\begin{array}{l}\text { Take-away food } \\
\text { shops and mobile } \\
\text { food stands }\end{array}$ & $<10$ & Profit \\
\hline $\mathrm{J}$ & $\begin{array}{l}\text { Third parties } \\
\text { (crowdfunding) }\end{array}$ & $\begin{array}{l}\text { Alternative } \\
\text { finance }\end{array}$ & 1 & 2012 & Other sports activities & $10-15$ & Loss \\
\hline & $\begin{array}{l}\text { Interviews and } \\
\text { internal } \\
\text { documentation }\end{array}$ & $\begin{array}{l}\text { Interviews and } \\
\text { internal } \\
\text { documentation }\end{array}$ & $\begin{array}{l}\text { Companies } \\
\text { House, } \\
\text { ONS }\end{array}$ & $\begin{array}{l}\text { Interviews, } \\
\text { Companies } \\
\text { House }\end{array}$ & $\begin{array}{l}\text { Interviews, } \\
\text { Companies House }\end{array}$ & $\begin{array}{l}\text { Interviews and } \\
\text { internal } \\
\text { documentation }\end{array}$ & $\begin{array}{l}\text { Companies } \\
\text { House }\end{array}$ \\
\hline
\end{tabular}

*SIMD (Scottish Indices of Multiple Deprivation), measures deprivation across multiple domains within local areas of approximately 1,500 population count: 1 - stands for the least deprived areas, 10 - for the most deprived ones. 


\begin{tabular}{|c|c|c|}
\hline Cases & Citations & Categories \\
\hline $\mathbf{A}$ & $\begin{array}{l}\text { "So what we were looking for was a value-add investor, an industry investor... They had a suite of investors, already lined up, they had } \\
\text { some of the best-known names in the beverage across Europe on their board. They also gave us the expertise, the access to other contacts, } \\
\text { and the other investors that were investing could see that there was a potential with this brand". }\end{array}$ & $\begin{array}{l}\text { Sharing expertise, } \\
\text { access to networks }\end{array}$ \\
\hline $\mathbf{B}$ & $\begin{array}{l}\text { "One of the investors helped me to run the business. Investors are, probably, better qualified to provide feedback. So, I turn to them first for } \\
\text { feedback. One of our investors contributed a lot of time to the company, so it's nice when you can get such an investor...". }\end{array}$ & Sharing expertise \\
\hline $\mathbf{C}$ & $\begin{array}{l}\text { "I didn't really know where I was going to get the money. And then I eventually found Princess Trust, and then I got other money from the } \\
\text { Edinburgh Loan Fund, then the bank also said that they would give me the same amount of money. And then - my mom, who helped us a } \\
\text { huge amount, doing the drama teaching, with staff training, other financial matters, and promotion". }\end{array}$ & $\begin{array}{l}\text { Sharing expertise, } \\
\text { access to networks }\end{array}$ \\
\hline D & $\begin{array}{l}\text { "And it would have eaten the way up, and in order just to get started, I'd have to give away a big chunk of my business. It's better to keep } \\
\text { the money in the family, it is what they say. So than rather than let the banks intervene... It's better that the business is owned entirely by... } \\
\text { Even if they did want an equity stake, it would be better that they [parents] had an equity stake, than some random external investor". }\end{array}$ & Ownership protection \\
\hline $\mathbf{E}$ & $\begin{array}{l}\text { "I considered wherever I could get the money. I didn't feel I needed too much, I needed enough to pay the rent. It's a way of funding things } \\
\text { [personal loans], that's an easy way to get money without giving away shares. Apart from with my partner. My then partner, it felt a bit } \\
\text { different letting him have some shares, because... you know, we've been together at that point for several years. I felt that would be fine as } \\
\text { keeping it in the family". }\end{array}$ & Ownership protection \\
\hline $\mathbf{F}$ & $\begin{array}{l}\text { "I had a business plan, I had sold products, so I could prove the market the validity of the concept, or what we had. I had IP rights. So, I felt } \\
\text { I was in a pretty good shape to attract the first round of proper investment if you can call it, and get some amount of money from } \\
\text { institutional investors or business angels. It seemed like a good fit. Not just from investment point of view, but also through...what they do } \\
\text { as a business. So there was a potential for them selling our products". }\end{array}$ & Ownership protection \\
\hline $\mathbf{G}$ & $\begin{array}{l}\text { "And the bank overdraft, obviously, was a facility... It was just a way of getting to the start line. This along with our own money and my } \\
\text { father's loan was all that we used to fund the cash flow, without sharing the ownership. [...] And that was great as he used to help us trying } \\
\text { to get the systems, and some discipline in place, and trying to have, you know, regular meetings... And get all our financial controls and } \\
\text { systems up and running. So he was really helpful. And things like appointing accountants, and appointing solicitors, in a way, he was quite } \\
\text { a good source of information...". }\end{array}$ & $\begin{array}{l}\text { Ownership protection, } \\
\text { sharing expertise }\end{array}$ \\
\hline $\mathbf{H}$ & $\begin{array}{l}\text { "I didn't have to borrow any money from a bank... Which obviously have advantages these days. Getting investment and family } \\
\text { involvement, probably, also helped me in my development within the company, and being linked to the global brands". }\end{array}$ & Access to networks \\
\hline $\mathbf{I}$ & $\begin{array}{l}\text { "I wanted to be independent, and show that I have done it myself. I was too young; I had never had credit from the bank. So I'd rather use } \\
\text { the money I got from my aunt, then ask more from the bank than go anywhere else. And when the initial costs were covered, I was in - I did } \\
\text { not need more". }\end{array}$ & Ownership protection \\
\hline $\mathbf{J}$ & $\begin{array}{l}\text { "We were quite proud that we did not ask anyone for [financial] help. And the more the business was developing we could see that we could } \\
\text { keep the money the business earns and put it back into the business. We did not want any investors, banks, overdrafts - nothing like that, just } \\
\text { to be able to sustain ourselves, and be independent and in control. So it worked out we did not succeed with the bank eventually..." }\end{array}$ & Ownership protection \\
\hline
\end{tabular}




\section{Table 4 Analytical theme 2: the preferred versus actual sequence of finance sources}

\begin{tabular}{|c|c|c|}
\hline Cases & Citations (reasoning for divergence) & Categories \\
\hline $\mathbf{A}$ & $\begin{array}{l}\text { "So, that was a really difficult period for us. We were almost at the point where we were thinking we were just not going to make it work. } \\
\text { So, we went to some family and friends that had known me from the previous life, and my professional career at ... and it was certainly not } \\
\text { our first choice, because in my experience mixing business with family and friends is fraught with danger. [...] It was a quick solution, it was } \\
\text { an easy solution, but it was certainly not done without, you know, a lot of thought and consideration to what impact it would have on our } \\
\text { personal lives.". }\end{array}$ & $\begin{array}{l}\text { Filling in gaps, fast } \\
\text { access, informal } \\
\text { funding as a last } \\
\quad \text { resort }\end{array}$ \\
\hline B & $\begin{array}{l}\text { "At one point I had more investors than I needed, so I tried to consolidate the investors, I tried to reduce the number if them. We were trying } \\
\text { to keep the ones, who were putting in more money. But my brother-in-law he wanted to invest, so I told the business angels that I didn't } \\
\text { need as much from them. [...] You have to be careful about involving family members in the business, when you've got a mixture of private } \\
\text { investors, and family and friends". }\end{array}$ & $\begin{array}{l}\text { Informal funding as a } \\
\text { second choice }\end{array}$ \\
\hline $\mathbf{C}$ & $\begin{array}{l}\text { "So, it ended up being quite a lot over the first year. So initially she was going to give me 5000, and then it was } 10000, \text { and then it was a } \\
\text { little bit extra, a little bit extra until it built up... And when I finally found the place, and I calculated exactly how much I would need, I was } \\
\text { short of a little bit. But I didn't go to anywhere else, because my mom had already a shortfall, so it was easy." }\end{array}$ & $\begin{array}{c}\text { Filling in gaps, fast } \\
\text { access }\end{array}$ \\
\hline $\mathbf{D}$ & $\begin{array}{l}\text { "So I went away, I did all the list of stuff that they [banks] wanted in order to strengthen the proposition, and more, actually. And then went } \\
\text { back to them } 6 \text { months later, and } 6 \text { months later, they were even less interested than they were in the first time I went to them. Then ...like, } \\
\text { for example, there were other people who may have considered giving me money, because they [parents] had observed that I'd taken some } \\
\text { steps of being proactive... This was the last remaining option." }\end{array}$ & $\begin{array}{l}\text { Filling in gaps, } \\
\text { informal funding as a } \\
\text { last resort }\end{array}$ \\
\hline $\mathbf{E}$ & $\begin{array}{l}\text { "And then we thought how to get greedy it and to expand more and more, so we hire a lot of new staff. [...] We were under resourced for the } \\
\text { growth that we had. So, yes, those sorts of things would be some of the overheads that were emerging rapidly, and we needed fast solutions. } \\
\text { [...] I felt he [then-partner] was the best person, because he ticked those boxes of trust...." }\end{array}$ & $\begin{array}{c}\text { Filling in gaps, fast } \\
\text { access }\end{array}$ \\
\hline $\mathbf{F}$ & $\begin{array}{l}\text { "At that stage it seemed as incredibly high risk, because we didn't even have a product yet. And that makes it more difficult to get the funds } \\
\text { from institutional investors, leaving us with fewer and less attractive options... That's why we relied on a bit more the personal attach, who } \\
\text { believe into you as a person... Alternatively, I certainly would have needed to find a bit more of money from someone else. It would have } \\
\text { possibly delayed me being able to access that smart grant fund." }\end{array}$ & $\begin{array}{c}\text { Filling in gaps, fast } \\
\text { access }\end{array}$ \\
\hline $\mathbf{G}$ & $\begin{array}{l}\text { "We knew from our business plan that we needed a certain amount of cash to pay for the rent, to buy computers, to buy a car, to pay for the } \\
\text { stationary, to employ someone, to furnish the offices... But our overheads started to go pretty fast... and we needed more cash to fund it. ... } \\
\text { and my dad saw that, and stepped in...". }\end{array}$ & $\begin{array}{c}\text { Filling in gaps, fast } \\
\text { access }\end{array}$ \\
\hline $\mathbf{H}$ & $\begin{array}{l}\text { "I suppose, to some extent I didn't get any cash to start-up, but I had their [parents'] contracts, and the money that I paid my parents for } \\
\text { the business came out of the business as it traded....And I don't know if the business would have grown the way it has. And it was necessary } \\
\text { to attract big players - institutional investors". }\end{array}$ & $\begin{array}{l}\text { Informal funding as a } \\
\text { stepping stone }\end{array}$ \\
\hline $\mathbf{I}$ & $\begin{array}{l}\text { "If not the [monetary] gift I got from my aunt, I would not even consider starting a business... I thought to put it to a good use. I would not } \\
\text { even go to the bank if not the realisation of the responsibility that I need to do it properly..." }\end{array}$ & $\begin{array}{l}\text { Informal funding as a } \\
\text { stepping stone }\end{array}$ \\
\hline $\mathbf{J}$ & $\begin{array}{l}\text { "Other options would have possibly delayed us [...] we did not like the idea sharing equity, and it would have meant...well, it would have } \\
\text { taken quite a bit longer... And a friend of ours shared this idea with us [crowdfunding], and we thought - why not!". }\end{array}$ & $\begin{array}{l}\text { Filling in gaps, fast } \\
\text { access }\end{array}$ \\
\hline
\end{tabular}




\begin{tabular}{|c|c|c|}
\hline Cases & Citations (sources of dynamism in decision-making) & Categories \\
\hline A & $\begin{array}{l}\text { "I mean, that [pitching for equity investment] was unsuccessful for a couple of reasons. I think we were underprepared. I think, the format } \\
\text { of the meeting was unsuitable. And they put us in the room with five individuals who didn't know each other. So, it wasn't a very easy } \\
\text { environment for pitching for money. [...] Then the petrol costs had grown up, the value of the pound went down, the margins on the } \\
\text { international basis went down. [...] We just lost } 20 \% \text { margin on based nothing rather than currency!" }\end{array}$ & $\begin{array}{l}\text { Unpreparedness as an } \\
\text { internal factor, } \\
\text { recession as an external } \\
\text { factor }\end{array}$ \\
\hline B & $\begin{array}{l}\text { "So we've only, may be got about 5-6 months what's the funding left in the business. And if we don't raise more investment then, I think, } \\
\text { we'll be out of business. [...] We've not had a sales team in our business. I don't think the product is the right product for the retail } \\
\text { market. I don't think we've got the merchandising right. I don't think the price point of the retail product is correct. I think, we've had } \\
\text { difficulties with our supply chain. And we're not making enough of the profit margin on the sales that we do make". }\end{array}$ & $\begin{array}{l}\text { The need for further } \\
\text { business development }\end{array}$ \\
\hline $\mathbf{C}$ & $\begin{array}{l}\text { "I just looked around and checked what was available out there locally [...]. I didn't really do any business side of the school. I was just } \\
\text { teaching, and organizing the staff, and appearance, and everything. But I didn't have any financial responsibility. And that was a lot of } \\
\text { learning, very quickly. Because I think...I was so passionate about what I do, that I was, may be, too positive about everything in the } \\
\text { beginning". }\end{array}$ & $\begin{array}{l}\text { Local infrastructure, } \\
\text { lack of expertise }\end{array}$ \\
\hline $\mathbf{D}$ & $\begin{array}{l}\text { "This was 2009-2010, so it was a very difficult thing to get money from the banks. If I'd done it in 2005-2006, they probably would have } \\
\text { just given me money. I tried once, but I wouldn't try more at that time..." }\end{array}$ & $\begin{array}{l}\text { Recession } \\
\text { external }\end{array}$ \\
\hline $\mathbf{E}$ & $\begin{array}{l}\text { "Again, the biggest thing that was hit during the recession. Obviously in } 2000, \text { we started in July, and in September } 2000 \text { there was that } \\
\text { downturn in the economy, we all thought it was the recession time, but we now know that it wasn't! [...] we, probably, would have } \\
\text { struggled to find finance in 2000, when the economy was bad, and during the last recession...". }\end{array}$ & $\begin{array}{l}\text { Recession as an } \\
\text { external factor }\end{array}$ \\
\hline $\mathbf{F}$ & $\begin{array}{l}\text { "Interacting with people, making sure that you can delegate your tasks to the right people, and then manage that, and make sure that the } \\
\text { people work for you and with you as a team, and deliver to your expectations. So, it's a different skill set. It requires a lot of } \\
\text { communication, a lot of structure... And I'm still learning that, you know... I'm still growing into this new role of becoming the managing } \\
\text { director. And then, unfortunately, the huge financial collapse happened, global recession, and that meant that there was simply no money } \\
\text { anywhere. And that was incredibly difficult, because...I needed money" }\end{array}$ & $\begin{array}{l}\text { Lack of expertise, } \\
\text { recession as an external } \\
\text { factor }\end{array}$ \\
\hline $\mathbf{G}$ & $\begin{array}{l}\text { "We didn't really worry about the economic situation, because there was a demand for recruitment company. There was a gap in the } \\
\text { market for a good recruitment company. We took it...it was difficult, it was a downturn, but nothing that affected us significantly. And the } \\
\text { market was going up... Probably, we could have gone more quickly, but we went quickly anyway". }\end{array}$ & $\begin{array}{l}\text { Recession as an } \\
\text { external factor }\end{array}$ \\
\hline $\mathbf{H}$ & $\begin{array}{l}\text { "It's more circumstances that anything else. But I think it's quite normal for people... there was a formal valuation done, but was very } \\
\text { informal how the money came in as the recession hit, and the prices fell down..." }\end{array}$ & $\begin{array}{l}\text { Recession as an } \\
\text { external factor }\end{array}$ \\
\hline I & "I just went to my local branch, as I had already got an account with them..." & Convenience \\
\hline $\mathbf{J}$ & $\begin{array}{l}\text { "We weren't really ready to invest more time into paperwork, as we have already started out classes... And then a friend of ours invited us } \\
\text { to this event just around the corner, where we met X - the founder of } Y \text { [an online crowdfunding platform]". }\end{array}$ & $\begin{array}{c}\text { Local networking } \\
\text { opportunities }\end{array}$ \\
\hline
\end{tabular}


Figure 1 A dynamic representation of the contemporary finance escalator

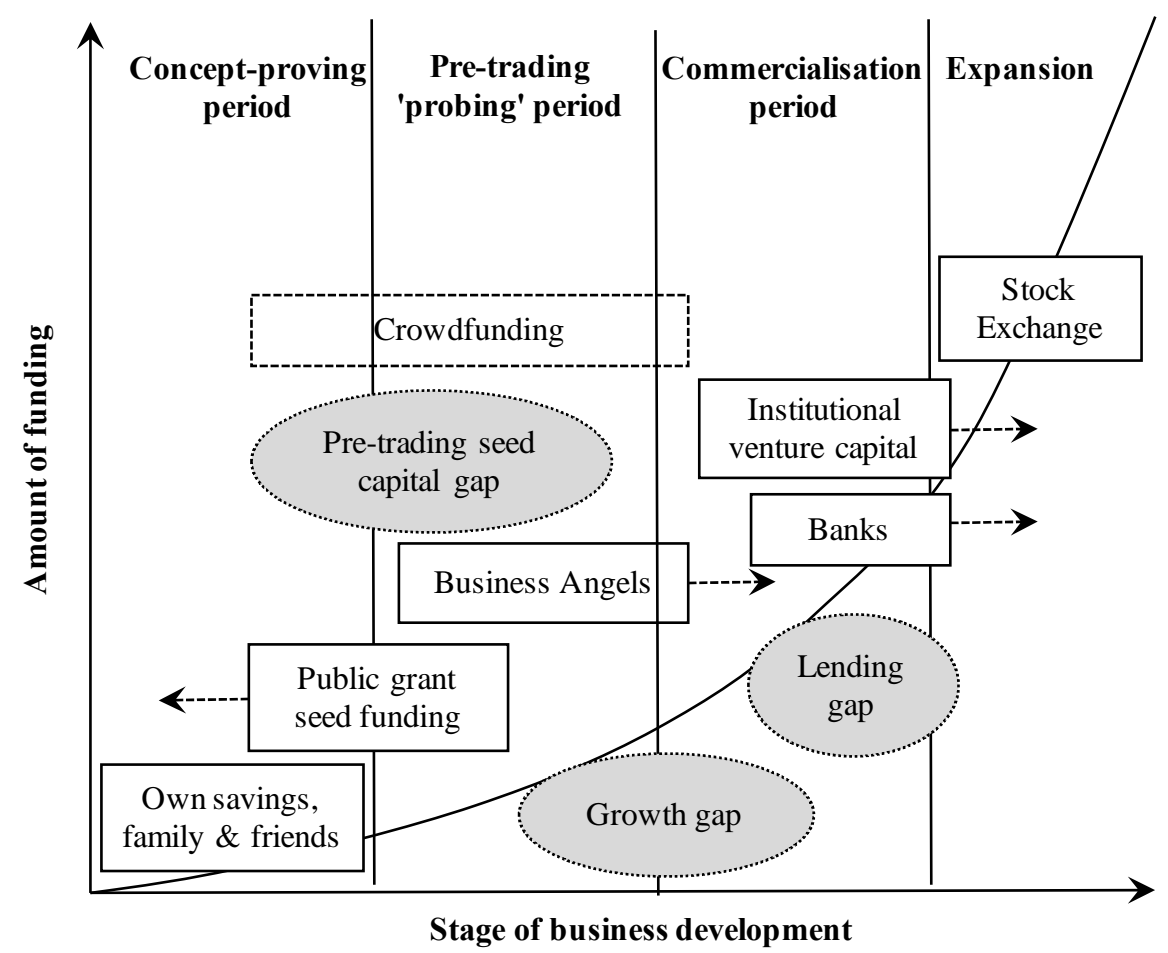


Figure 2 Individual funding journeys: Cases A, B, F and $\mathrm{H}$

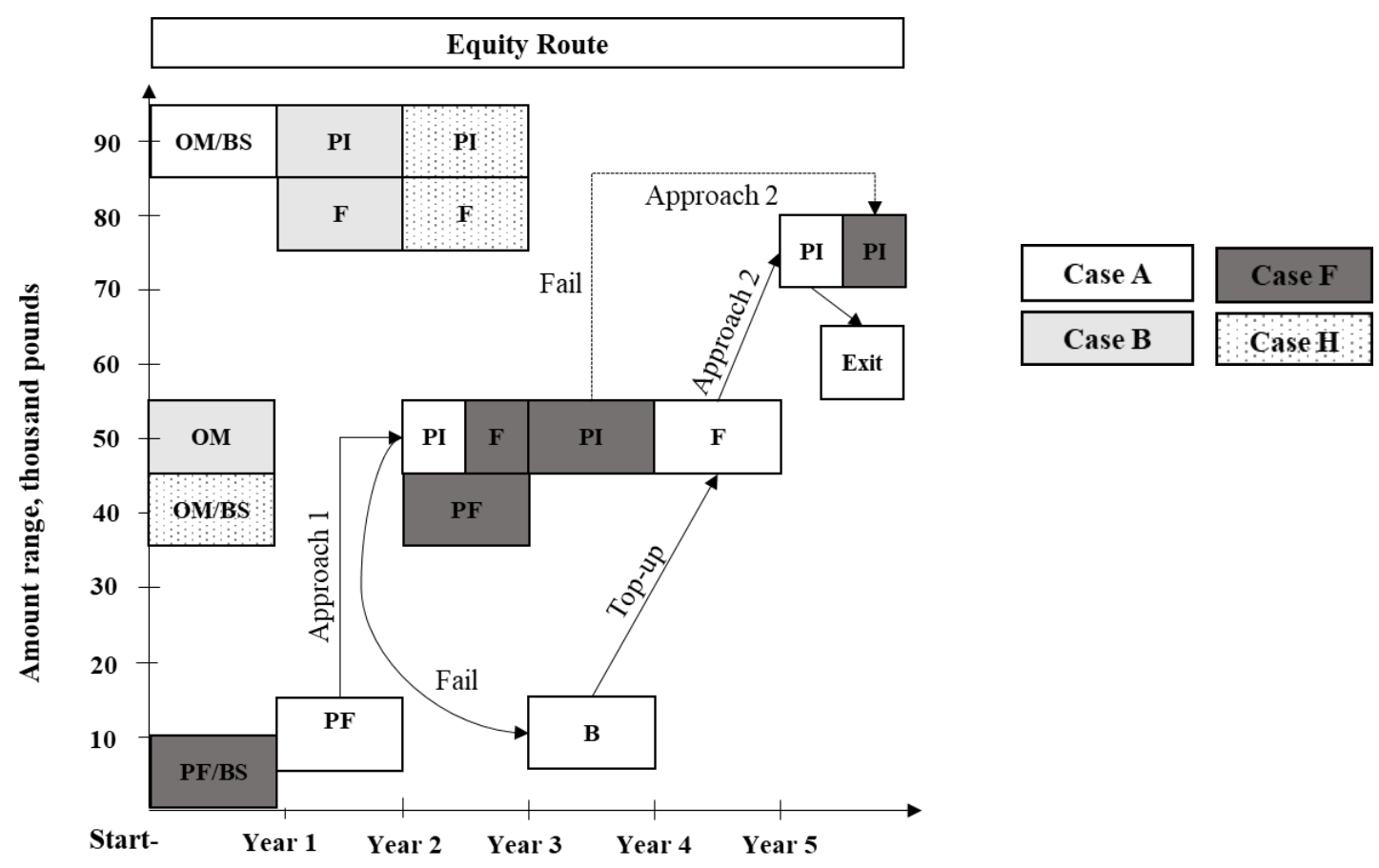

OM - own money BS - bootstrapping $\quad \mathbf{F}$ - family or friends $\quad \mathbf{B}$ - bank PF - public funds PI - private investor(s) 
Figure 3 Individual funding journeys: Cases C, D, and G

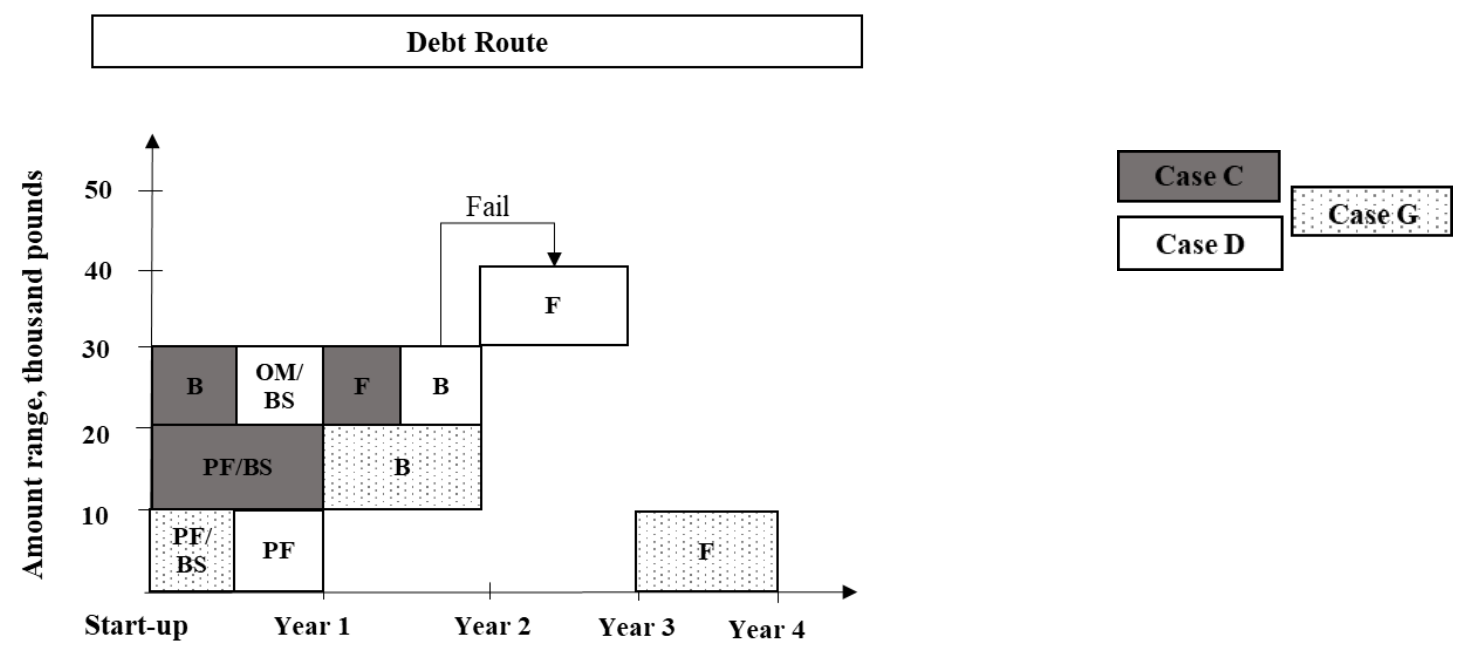

OM - own money PF - public funds

BS - bootstrapping $\quad \mathbf{F}$ - family or friends $\quad \mathbf{B}$ - bank PI - private investor(s) 
Figure 4 Individual funding journeys: Cases E, J, and I

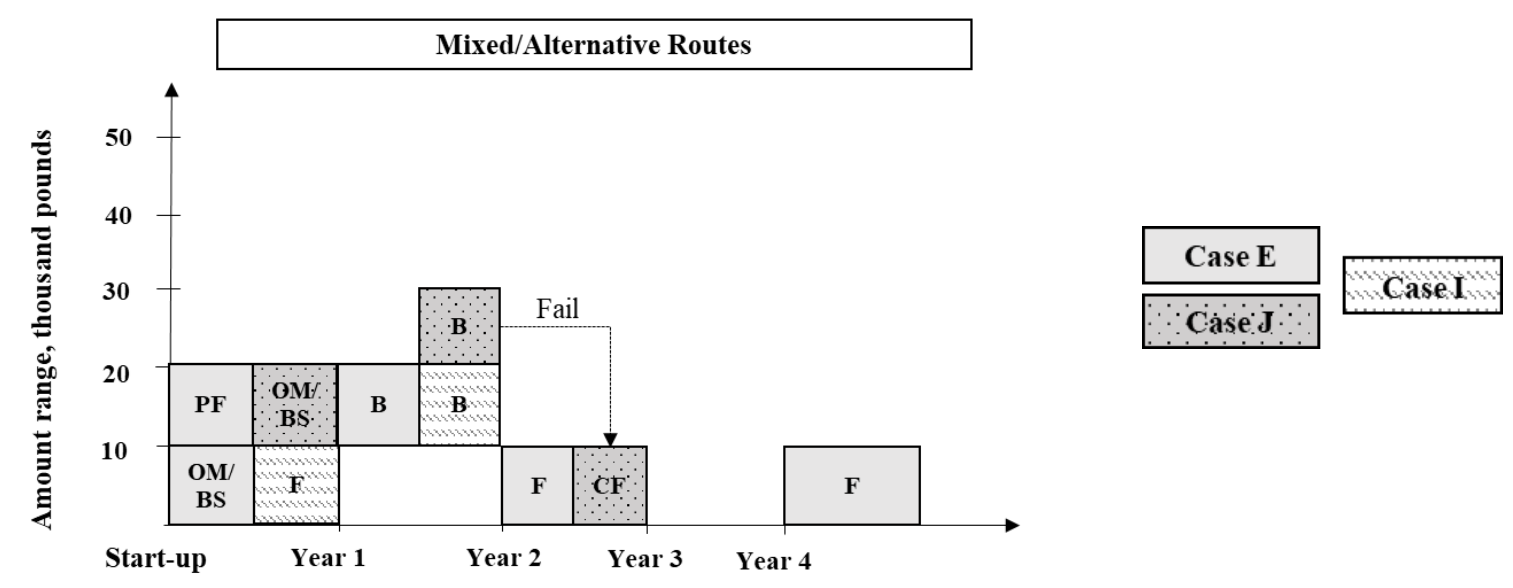

$\begin{array}{ll}\mathbf{O M} \text { - own money } & \mathbf{B S} \text { - bootstrapping } \quad \mathbf{F} \text { - family or friends } \quad \mathbf{B} \text { - bank } \\ \mathbf{P F} \text { - public funds } & \text { PI - private investor(s) }\end{array}$ 
Figure 5 Re-visited finance escalator
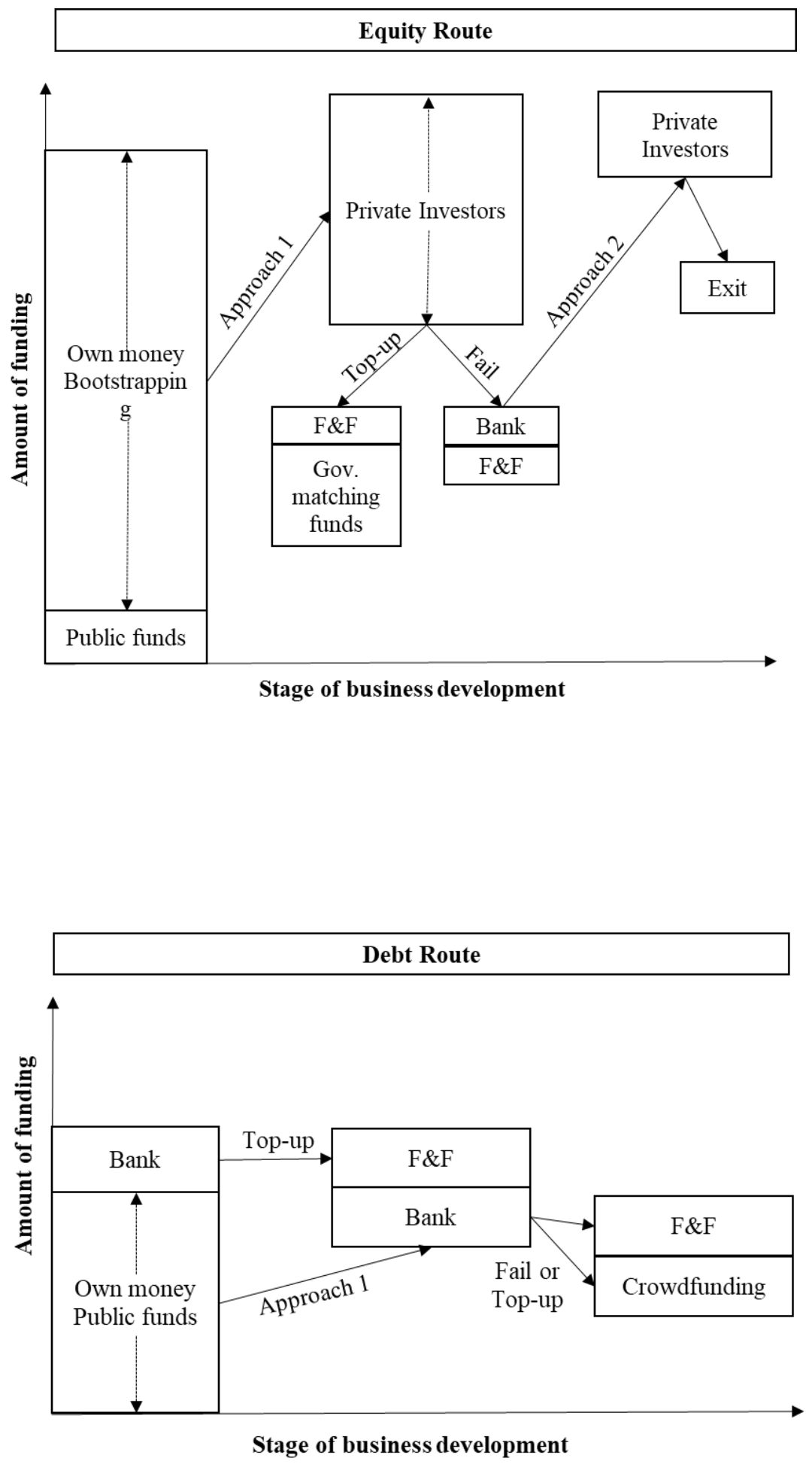


\section{Figure Captions}

Figure 1 A dynamic representation of the contemporary finance escalator

Figure 2 Individual funding journeys: Cases A, B, F and H

Figure 3 Individual funding journeys: Cases C, D, and G

Figure 4 Individual funding journeys: Cases E, J, and I

Figure 5 Re-visited finance escalator 